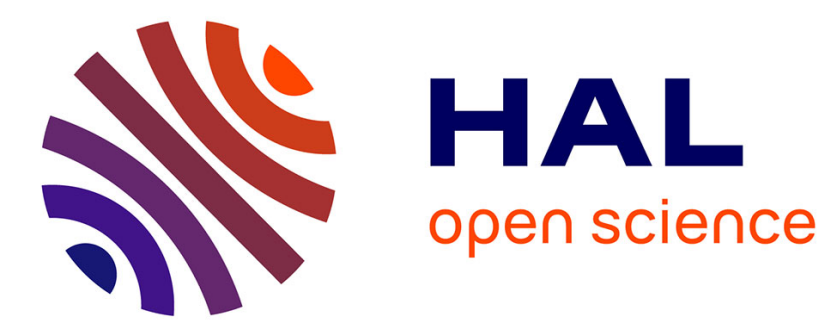

\title{
The two-level tonal system of Lataddi Narua
}

Roselle Dobbs, Lǎ Míngqīng

\section{To cite this version:}

Roselle Dobbs, Lă Míngqīng . The two-level tonal system of Lataddi Narua. Linguistics of the Tibeto-Burman Area, 2016, 39 (1), pp.67-104. 10.1075/ltba.39.1.04dob . halshs-02945164

\section{HAL Id: halshs-02945164 \\ https://shs.hal.science/halshs-02945164}

Submitted on 22 Sep 2020

HAL is a multi-disciplinary open access archive for the deposit and dissemination of scientific research documents, whether they are published or not. The documents may come from teaching and research institutions in France or abroad, or from public or private research centers.
L'archive ouverte pluridisciplinaire HAL, est destinée au dépôt et à la diffusion de documents scientifiques de niveau recherche, publiés ou non, émanant des établissements d'enseignement et de recherche français ou étrangers, des laboratoires publics ou privés.

\section{(2)(1) $\$$}

Distributed under a Creative Commons Attribution - NonCommercial - ShareAlikel 4.0 
Preprint version of: Dobbs, Roselle \& Mingqing La. 2016. The two-level tonal system of Lataddi Narua. Linguistics of the Tibeto-Burman Area 39(1). 67-104.

\title{
THE TWO LEVEL TONAL SYSTEM OF LATADDI NARUA* Roselle Dobbs and Lă Míngqīng 喇明清
}

\begin{abstract}
Lataddi Narua is the first reported variety of a Naish language having only two tonal levels; all other Naish languages described to date have three. The language uses a system in which level tones are primary, and tones are associated to lexical items rather than to individual syllables. Four tone categories are identified for nouns and adjectives, and six for verbs. Processes of tonal interaction across word boundaries are discussed, from tonal morphology to observations about syntactic and semantic factors influencing the placement of tone group boundaries within a sentence.
\end{abstract}

Keywords: tone; level tone; tonal morphology; Narua; Mosuo; Yongning Na; Naish languages.

\section{INTRODUCTION}

While the study of Naish languages is well underway, all of those described to date are reported to have three tonal levels. These include several dialects of Naxi (Hé \& Jiāng 1985; Michaud 2006; Michaud \& He Xueguang 2007; Michaud and He Likun 2015; Pinson 1997), three varieties of Narua (Lidz 2010; Michaud 2008, 2015; Yang 2006, 2009), and Laze $^{1}$, a language spoken in Muli County (Michaud 2009, 2013). This study aims to contribute to the study of tone in Naish languages by presenting a system that makes use of only two tonal levels. It also adds to the growing body of data pertaining to Sino-Tibetan languages in which level, rather than contour, tones are primary, a typological feature once considered to occur predominantly in African languages (Hyman \& VanBik 2002; Hyman 2007 on Kuki-Chin; Evans 2008 on Qiang; Sun 1997 on Tibetan).

\footnotetext{
* The first author wishes to thank Lă Míngqīng 喇明清, Lă Qiăoyuè 喇巧月 and Lă Míngyīng 喇明英 for their insightful and detailed explanations, as well as their superhuman patience, and their extended family and other $\mathrm{Na}$ people of Wuzhiluo village for their time, hospitality, generosity and good humour. Heartfelt thanks also to Alexis Michaud for his generous guidance and encouragement, to David Bradley, Picus Ding, Liberty Lidz and Thomas Pinson for their linguistic input, and to the anonymous reviewers who provided detailed and helpful feedback. Thanks are also due to our spouses, Peter Dobbs and Wú Jùn 吴俊 for putting up with our linguistic habits. Any errors and/or misrepresentations in this paper are, of course, entirely the authors' own responsibility.

Glossing of grammatical items in this paper follows the Leipzig conventions found at http://grammar.ucsd.edu/courses/lign120/leipziggloss.pdf

${ }^{1}$ Sìchuān shěng, Mùlǐ Zàngzú zìzhìxiàn, Xiàngjiăo xiāng 四川木里藏族自治县项脚乡.
} 
Lataddi Narua [la $t^{\mathrm{h}} \mathrm{a}$ ldil naJzwrV] (hereafter LTD Narua) is a variety of the language recently given Ethnologue status as Narua [nru]. ${ }^{2}$ Also known as Eastern Naxi, Mosuo or $\mathrm{Na}$, this language classification coincides with the three eastern dialects of Naxi identified by Chinese linguists in the late 1970's (Hé \& Jiāng 1985:104-116). Regarding the position of Narua within Sino-Tibetan, Jacques and Michaud (2011) propose Narua (labelled "Na/Mosuo") as one of three "Naish" languages in the "Naic" sub-group of the "Na-Qiangic" branch of Burmo-Qiangic. The other two Naish languages are Naxi and Laze (see Figure 1).

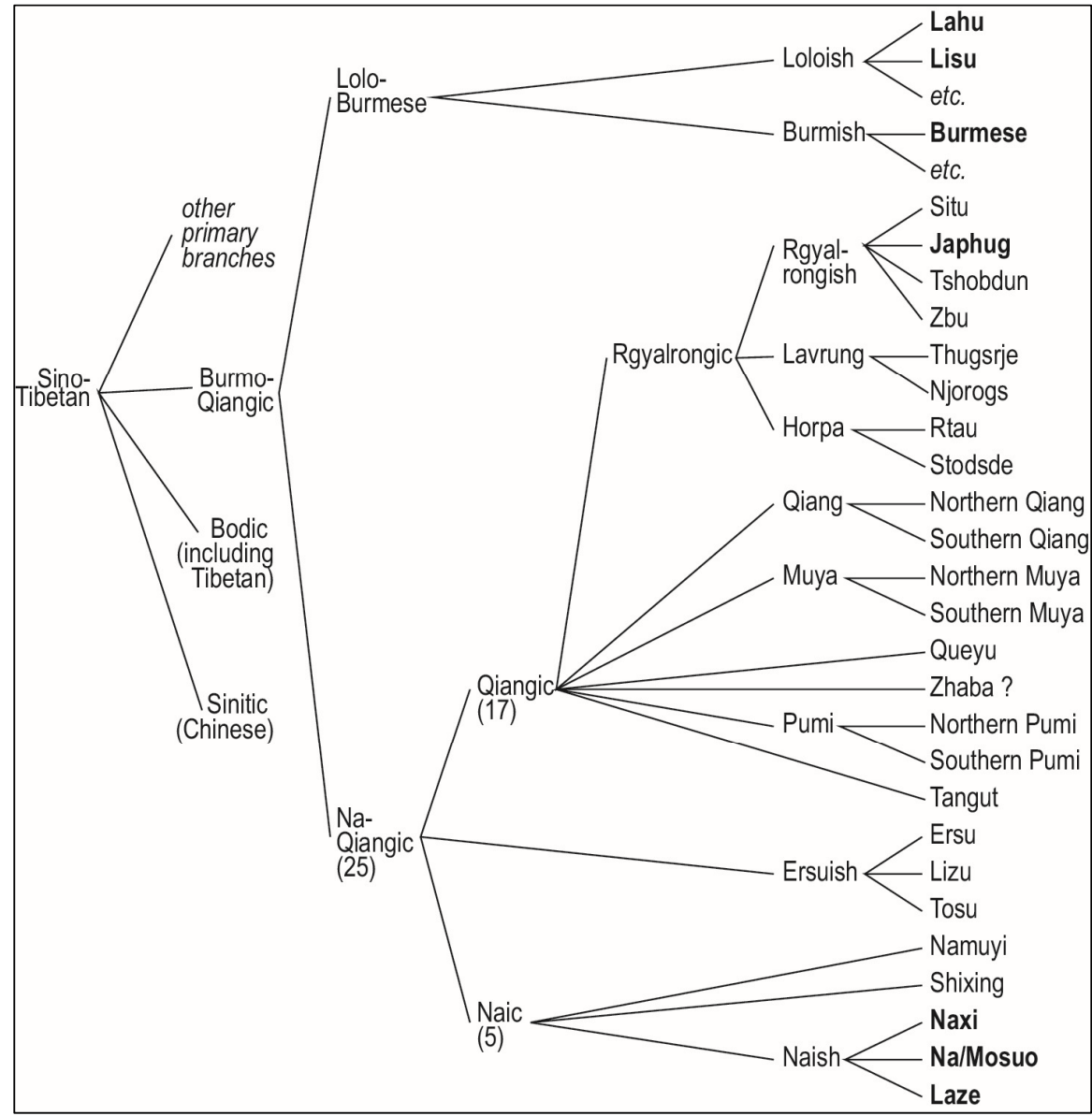

Figure 1. Tentative family tree showing the position of Narua (Na/Mosuo) within the NaQiangic sub-branch of Sino-Tibetan. (Jacques \& Michaud 2011, used with permission.)

Within Na-Qiangic, but outside of the Naish sub-group, two tonal levels are reported in several dialects of Pumi (Ding 2001; Jacques 2011; Daudey 2014). Within the Naic sub-branch, Shǐxīng (史兴), also known as Xùmǐ (旭米), a

\footnotetext{
${ }^{2}$ The former ethnologue code for Naxi [nbf] has been retired. It has been split into Naxi [nxq] (previously categorised as the western dialects of Naxi), and Narua [nru] (previously categorised as the eastern dialects of Naxi). See http://www.ethnologue.com/language/nru
} 
language spoken in Muli Tibetan Autonomous County of Sichuan Province, ${ }^{3}$ is also reported to make use of two tonal levels (Chirkova \& Michaud 2009).

Early studies on Naish languages by Hé \& Jiāng (1985) describe six "Naxi dialects" - three "western" and three "eastern" - all having three tonal levels and with tone assigned to individual syllables. It has since been confirmed that (western) Naxi makes use of three tonal levels and that it tends towards the omnisyllabic type (one tone per syllable). Processes of tonal reassociation are few (Michaud 2006; Michaud \& He Xueguang 2007; Pinson 1997). More recent research, however, has revealed that the tones of some dialects of Naish languages are not associated to syllables at all. Rather, they are associated to lexical items (Michaud 2008).

Three varieties of Narua have been described to date. These all fall within the geographic area of the central (Yongning) dialect of "eastern Naxi". Material already published includes descriptions of Narua as it is spoken in:

1. Pingjing Village, ${ }^{4}$ on the northern edge of Yongning Township in Ninglang Yi Autonomous County, Yunnan Province (see Michaud 2008, 2015). Data is also available online in the Pangloss Collection ${ }^{5}$ (Michailovsky et al. 2014). Pingjing Narua (hereafter PJ Narua) makes use of three tonal levels. Tones are associated, not to syllables, but to lexical items, and each lexical item belongs in a tonal class. Five tonal classes have been identified for monosyllabic nouns and eleven for disyllabic nouns.

2. Luoshui Village ${ }^{6}$ on the southwestern edge of Lugu Lake in Ninglang Yi Autonomous County (see Lidz 2010). The tonal system of Luoshui Narua calls for further analysis. Surface phonological tones are transcribed employing three tonal levels, but a reanalysis in terms of two levels would seem possible in many cases. Mention is made of prolific tone sandhi processes, but tantalisingly, these processes are not elaborated on.

3. Abuwa Village ${ }^{7}$ on the south edge of Yongning Township, by native speaker Yáng Zhènhóng 杨振洪 (2006, 2009). This description employs three tonal levels and is syllable-based, but notational inconsistencies suggest that there is room for further analysis.

The following description of the LTD Narua tonal system introduces further diversity.

\footnotetext{
${ }^{3}$ Sìchuān shěng, Mùlǐ Zàngzú zìzhìxiàn, Shuǐluò xiāng 四川省木里藏族自治县水洛乡.

${ }^{4}$ Yúnnán shěng, Lìjiāng shì, Nínglàng Yí zìzhìxiàn, Yǒngníng xiāng, Píngjìng cūn 云南省丽江 市宁蒗彝族自治县永宁乡平静村.

${ }^{5} \mathrm{YN}$ Na recordings of a speaker from Pingjing Village and transcripts can be found online at http://lacito.vjf.cnrs.fr/pangloss/languages/Na_en.htm.

${ }^{6}$ Yúnnán shěng, Lìjiāng shì, Nínglàng Yí zìzhìxiàn, Yǒngníng xiāng, Luòshuǐ cūn 云南省丽江 市宁蒗彝族自治县永宁乡落水村.

${ }^{7}$ Yúnnán shěng, Lìjiāng shì, Nínglàng Yí zìzhìxiàn, Yǒngníng xiāng, Ābùwă cūn 云南省丽江 市宁蒗彝族自治县永宁乡阿布瓦村.
} 


\section{BACKGROUND AND METHOD}

The variety of Narua under study here - LTD Narua - also falls within the geographic area of the Yongning dialect of "eastern Naxi". Rather than being found in Yunnan Province, though, it is spoken in and around the swamp area known as the Grass Sea (căo hăi 草海), which forms the eastern end of Lugu Lake (Lúgūhū 泸沽湖) in Yanyuan County, Liangshan Yi Autonomous Prefecture, Sichuan Province (see map below). Its speakers are classified as Mongolian (Měngzú 蒙族); their autonym is $\mathrm{Na}$ [na/]. The word Lataddi [la $\mathrm{t}^{\mathrm{h}} \mathrm{a}$ ldiv] is a compound meaning 'Lata land', i.e. the land of the Lata clan.

Data was collected primarily during 2008-2010 with native speakers from Wuzhiluo, ${ }^{8}$ a sub-village of Boshu Village on the northern edge of the swamp. Data collection and elicitation were conducted both in Wuzhiluo itself and in Chengdu, the capital city of Sichuan Province.

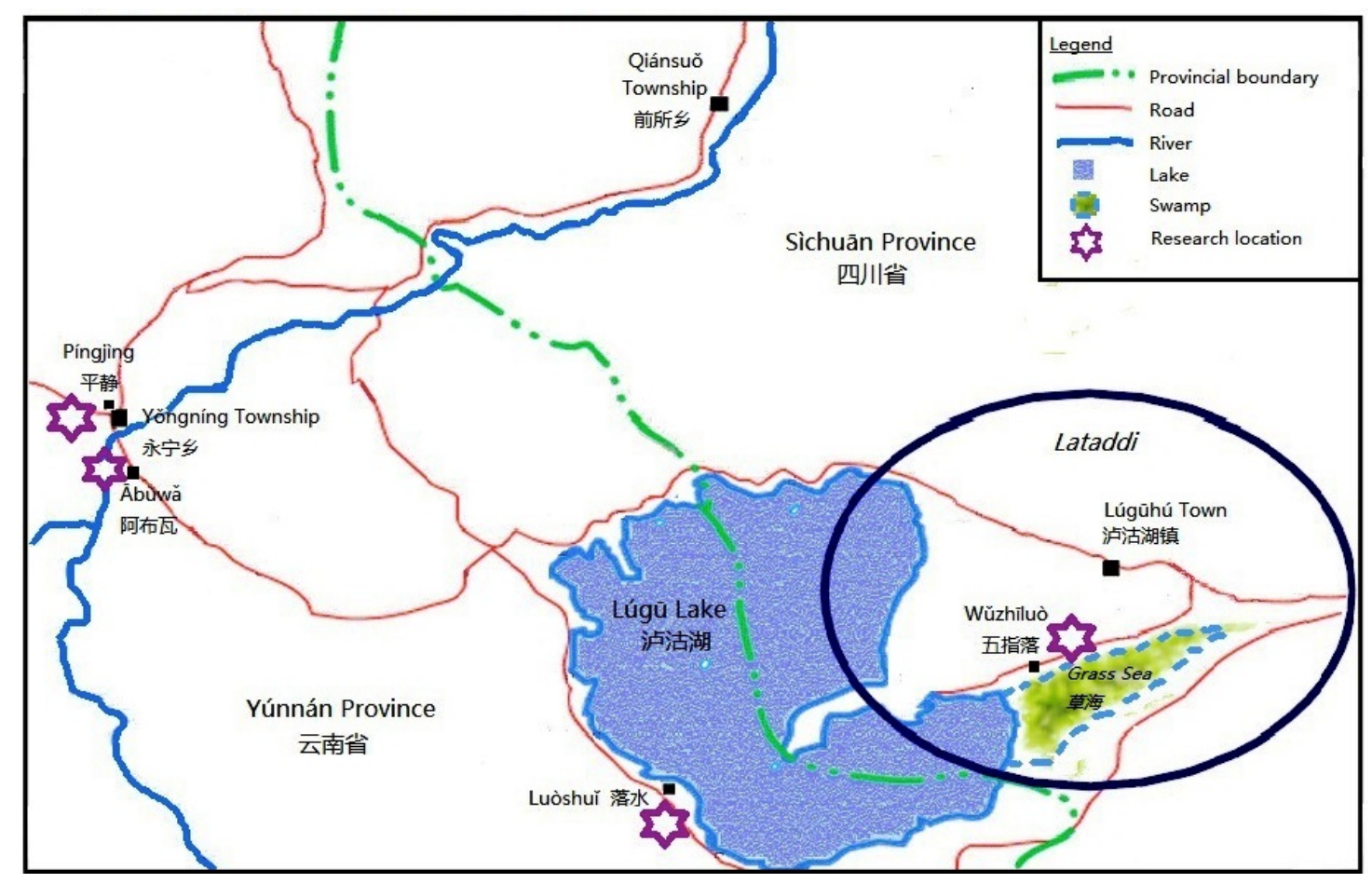

Figure 2. Map showing locations of Lataddi and of Narua research

The choice to study this particular variety of the language was nothing more or less profound than the availability of a native speaker who was willing to be a language consultant: the second author, Lă Míngqīng 喇明清. ${ }^{9}$ Research initially began in 2008 with weekly language learning and recording sessions in Chengdu, during which both elicited data and natural text were recorded electronically and transcribed using IPA. The second author's niece, Lă Qiăoyuè 喇巧月, and sister, Lă Míngyīng 喇明英, provided additional data. Several field trips to the area were

\footnotetext{
${ }^{8}$ Sìchuān shěng, Liángshān Yí zìzhìzhōu, Yányuán xiàn, Bóshù cūn, Wǔzhǐluò 四川省凉山彝 族自治州盐源县沪沽湖镇博树村五指落.

${ }^{9}$ Lă Míngqīng 喇明清 is a professor of ethnic culture and tourism at Southwest University for Nationalities (Xīnán Mínzú Dàxué西南民族大学) in Chengdu.
} 
made, including two trips by the first author in 2009 and 2010 with the express purpose of verifying the existence of certain phonemes and tonal contrasts. During the course of these and other trips, a number of other native speakers also provided data. Contact has been maintained with several of these people and their families. A wordlist containing some 2000 items has been compiled, along with texts of various lengths, using the SIL FLEx software package. Three short LTD Narua texts are given in the appendix.

\section{OUTLINE OF FINDINGS}

\subsection{Two tonal levels}

LTD Narua is described in terms of two phonological tonal levels: [H] (high) and [L] (low). This is significant in that it differs from all other Naish languages, dialects, and varieties documented to date. Research currently being carried out by $\mathrm{Jì} \mathrm{X} \overline{1}$ 季惜 and $\overline{\mathrm{A}}$ Huì 阿慧 (two MA students at Yunnan University) also suggests a two-level tonal system. This variety of Narua is spoken in Shankua, ${ }^{10} \mathrm{a}$ village also identified as being located in Lataddi, directly south of Wuzhiluo on the southeastern side of Lugu Lake and just inside the Yunnan border.

The tonal system of LTD Narua is one of level tones. While surface tonal contours exist, there is phonological evidence for a decomposition into levels. For example, evidence exists that a rising contour is made up of a combination of a $\mathrm{L}$ tone and a $\mathrm{H}$ tone. Tone spreading patterns are presented in Section 8.

Four tone categories have been identified for LTD Narua nouns and adjectives: $/ \mathrm{H} /$, / HL/, /LH/, and /L/. These are summarised in the tables below. Throughout this paper, tonal categories are indicated with an upper case letter inside slashes, e.g. $/ \mathrm{H} /$. Following Michaud (2008), superscript letters indicate the tonal categories of lexical items. Tonal categories of nouns and adjectives are discussed in more detail in Sections 4 and 5 respectively.

\begin{tabular}{|c|c|c|c|c|}
\hline $\begin{array}{c}\text { Tone } \\
\text { category }\end{array}$ & $\begin{array}{r}\text { Mono: } \\
e\end{array}$ & $\begin{array}{l}\text { llabic noun } \\
\text { ample }\end{array}$ & $\begin{array}{r}\text { Disyl } \\
\text { ex }\end{array}$ & $\begin{array}{l}\text { ic noun } \\
\text { ple }\end{array}$ \\
\hline$/ \mathrm{H} /$ & $\mathrm{H}_{\mathrm{ji}}$ & 'cow' & ${ }^{\mathrm{H}}$ bæ.mi & 'duck' \\
\hline /HL/ & $\mathrm{HL}_{\mathrm{jo}}$ & 'sheep' & ${ }^{\mathrm{HL}}$ lo.kr & 'rib' \\
\hline /LH/ & ${ }^{\mathrm{LH}} \mathrm{t}_{\mathfrak{S}^{\mathrm{h}} \mathfrak{x}}$ & 'deer' & ${ }^{\mathrm{LH}}$ hwr.li & 'cat' \\
\hline /L/ & $\mathrm{L}_{\text {ZUU }}$ & 'monkey' & Lbi.mi & 'axe' \\
\hline
\end{tabular}

Table 1. Tonal categories of nouns

${ }^{10}$ Yúnnán shěng, Lìjiāng shì, Nínglàng Yí zìzhìxiàn, Yǒngníng xiāng, Luòshuǐ cūn, Shānkuă xiăozǔ 云南省丽江市宁蒗彝族自治县永宁乡落水村山垮小组. 


\begin{tabular}{|c|c|c|c|c|}
\hline $\begin{array}{c}\text { Tone } \\
\text { category }\end{array}$ & \multicolumn{2}{|c|}{$\begin{array}{c}\text { Monosyllabic } \\
\text { adjective example }\end{array}$} & \multicolumn{2}{|c|}{$\begin{array}{c}\text { Disyllabic } \\
\text { adjective example }\end{array}$} \\
\hline /H/ & ${ }^{\mathrm{H}} \mathrm{f \gamma}$ & 'wide' & ${ }^{\mathrm{H}} \mathrm{mụ.næ}$ & ' soft' \\
\hline /HL/ & ${ }^{\mathrm{HL}} \mathrm{du}$ & 'big' & ${ }^{H L}$ gọ.dzuU & 'angry' \\
\hline /LH/ & ${ }_{\mathrm{SW}}^{\mathrm{LH}}$ & 'new' & ${ }^{\mathrm{LH}} \mathrm{kwæ.tswæ}$ & 'crooked' \\
\hline /L/ & $\mathrm{L}_{\mathrm{t} 6 \mathrm{i}}$ & 'small' & Lla.go & ' bent' \\
\hline
\end{tabular}

Table 2. Tonal categories of adjectives

The tonal categories of verbs are more elusive than those of nouns and adjectives, and are not yet fully understood. Verbs are usually monosyllabic and their tonal realisations tend to be influenced by the preceding phonological environment. Six tonal categories have been identified, also employing two tonal levels, but not yet given descriptive labels. These are summarised below. The tonal behaviour of verbs as understood at this point is discussed in more detail in Section 9.

\begin{tabular}{cll}
$\begin{array}{c}\text { Tone } \\
\text { category }\end{array}$ & \multicolumn{2}{c}{ Verb } \\
\hline 1 & ${ }^{1} \mathrm{dzumple}$ \\
\hline 2 & ${ }^{2} \mathrm{dzi}$ & 'eat' \\
3 & ${ }^{3} \mathrm{t} 6^{\mathrm{h}} \mathrm{sit}$ & 'sell' \\
4 & ${ }^{4} \mathrm{gu}$ & 'make' \\
5 & ${ }^{5} \mathrm{q}^{\mathrm{h}} \mathrm{wæ}$ & 'smash' \\
6 & ${ }^{6} \mathrm{la}$ & 'hit' \\
\hline
\end{tabular}

Table 3. Tonal categories of verbs

\subsection{Tones associated to lexical items}

Unlike (western) Naxi dialects, LTD Narua tonal categories are associated to lexical items rather than to individual syllables. This has also been reported in PJ Narua (Michaud 2008). The first indication that this may be the case in LTD Narua emerged at the outset of the research when it was observed, for example, that [seV] 'meat' is pronounced with a high-falling tone in isolation, but that in compound with various 'animal' morphemes, its surface tone varies, as seen in Table 4 below. Note that in the words 'beef' and 'venison', the surface tone on 'meat' is high-falling, while in 'mutton' and 'monkey meat' it is low-rising. (Tonal behaviour of compounds is discussed in more detail in Section 6.) As in the table below, Chao letters in tables and examples throughout this paper show surface phonological tone. Surface tones of lexical items are given in isolation form in all tables, unless otherwise stated.

\footnotetext{
${ }^{11}$ There are two apicalised vowels that occur after the alveolar fricatives and affricates $/ \mathrm{s}, \mathrm{z}, \mathrm{ts}^{\mathrm{h}}$, ts, dz/ in LTD Narua. For the purposes of consistency with previous research on Narua, these are transcribed phonemically as $/ \mathrm{w} /$ and $/ \mathrm{i} /$. However, it should be noted that, in this phonological environment, the vowel that Michaud (2008) transcribes as /i/ for PJ Narua corresponds to /u/ in Lidz' (2010) description of Luoshui Narua, and vice versa.
} 


\begin{tabular}{|c|c|c|c|c|c|c|c|}
\hline \multicolumn{2}{|c|}{$\begin{array}{l}\text { Component } 1 \\
\text { isolation tone }\end{array}$} & \multicolumn{4}{|c|}{$\begin{array}{l}\text { Component } 2 \\
\text { isolation tone }\end{array}$} & \multicolumn{2}{|c|}{$\begin{array}{c}\text { Compound } \\
\text { surface tones }\end{array}$} \\
\hline jiV & 'cow' & + & seV & 'meat' & $\rightarrow$ & jilseveV & 'beef' \\
\hline joV & 'sheep' & + & seV & 'meat' & $\rightarrow$ & jolșe/ & 'mutton' \\
\hline ts ${ }^{\mathrm{h}} æ 1$ & 'deer' & + & sel & 'meat' & $\rightarrow$ & $\left.\mathrm{ts}^{\mathrm{h}} \mathfrak{\mathrm { h }}\right\rfloor \mathbf{s e V}$ & 'venison' \\
\hline zul & 'monkey' & + & seV & 'meat' & $\rightarrow$ & zuJsel & 'monkey meat' \\
\hline
\end{tabular}

Table 4. Examples showing surface tones of 'meat' morpheme in various 'animal-meat' compounds

In many cases in LTD Narua, such as those in the compounds shown in Table 4 , it is the tonal category of the first morpheme of a word that determines the tonal output of the lexical item. A similar system is seen in Wadu Pumi where "tonal behaviour in compounding is often based on the tone of the first element, but is not always predictable" and where "(t)ones can spread rightwards as the tonal domain is extended by toneless clitics or when two tonal domains merge" (Daudey 2014:64).

\subsection{Tone groups and tone group boundaries}

A tone group in LTD Narua is headed by a lexical item. However, it is not necessarily restricted to that item, but may extend across more than one word within a clause. The break between one tone group and the next is referred to as a tone group break. The lexical item which determines the tonal category of the tone group is said to head the tone group.

In example sentences, tone groups breaks are indicated by vertical lines: pecked lines show mid-clause tone group breaks; solid lines indicate clause boundaries (which are also tone group breaks). Surface phonological tone is shown in the first row, and the tonal category for each tone group in the sentence is indicated in the second row, as exemplified below.
(1)

\begin{tabular}{|c|c|c|c|c|}
\hline & $\begin{array}{l}\text { sol-kv」 } \\
\text { /HL/ }\end{array}$ & $\mathrm{dzo} /$ & $\begin{array}{l}\text { grl-bụl } \\
\text { /H/ }\end{array}$ & $\begin{array}{l}\mathrm{ts}^{\mathrm{h}} \mathrm{v} / \mathrm{miV} \\
/ \mathrm{H} /\end{array}$ \\
\hline $\begin{array}{l}\text { person } \\
\text { zol } \\
\text { /H/ }\end{array}$ & $\begin{array}{l}\text { three-CLF } \\
\text { durl-luvV }\end{array}$ & $\begin{array}{l}\text { EXIST }^{12} \\
\text { grV } \\
\text { /H/ } /\end{array}$ & $\begin{array}{l}\text { 1SG-POSS } \\
\text { sol-kט̣/ } \\
\text { /HL/ }\end{array}$ & wife \\
\hline & one-CLF & $1 \mathrm{SG}$ & three- CLF & \\
\hline
\end{tabular}

A tone group may be as short as one monosyllabic word, such as those comprised of [hĩ] 'person' and [yr] '1SG' in sentence (1) above. Conversely, it may extend over a number of syllables, such as in sentence (2) below, where the second tone group covers six syllables comprised of a number-classifier combination, a locative, and a verb phrase.

${ }^{12}$ EXIST: Existential verb 


\section{(2) th $^{\text {h }}$ ไəł-sol-во 1 $:$ sol-lu」 qo」lo」 so」 se」 /H/ book-study-place THREE-CLF in study PFV '(I) studied in three schools.'}

As these examples suggest, division into tone groups is often syntactically motivated. However, there are also semantic motivations for the division of tone groups, as discussed further in Section 7.2.

\section{NOUNS}

The majority of LTD Narua nouns are disyllabic. In isolation, they appear with one of four surface tonal patterns, which can be analysed in terms of [H] and [L] tonal levels. Examples are given in the table below.

\begin{tabular}{|c|c|c|}
\hline $\begin{array}{c}\text { Isolation } \\
\text { tones }\end{array}$ & \multicolumn{2}{|c|}{$\begin{array}{c}\text { Disyllabic noun } \\
\text { example }\end{array}$} \\
\hline $1 \mathrm{~V}$ & bælmiV & 'duck' \\
\hline 11 & tolkr/ & 'rib' \\
\hline$」 V$ & hwr Jliv & 'cat' \\
\hline$\rfloor \Lambda$ & bi」mi/ & 'axe' \\
\hline
\end{tabular}

\section{Table 5. Isolation tones of disyllabic nouns}

It was observed early in the research that, similar to the way in which the surface tone on the syllable 'meat' was seen to vary when in compound with an 'animal' morpheme, when a disyllabic noun was placed in a phrase with the copular verb [ni/ $]^{13}$ or the verb [t $\left.{ }^{\mathrm{h}}{ }^{\mathrm{iV}}\right]$ ] 'to like', surface tonal realisations of the verb varied depending on the tone pattern of the noun. Moreover, the tonal output of the noun+verb was consistent, regardless of which verb was paired with the noun. From this starting point, various combinations of nouns from each of the four tone pattern groups were studied, some of them elicited, others from texts, in combination with various verbs, adjectives and other nouns, and it was concluded that there are four tonal categories for disyllabic nouns. A simple sentence with the demonstrative pronoun and the copular verb was chosen as a convenient frame for determining their tonal categories, as the copula readily associates with any noun.

In the environment of the frame $\mathrm{DEM}+\mathrm{N}+\mathrm{COP}$ 'this is (noun)', the surface tonal realisation of the second syllable of a disyllabic noun appears, not as a contour as it is in isolation, but as a level tone. A contour then appears on the verb. Table 6 below presents examples of disyllabic nouns with the copula. Note that the

\footnotetext{
${ }^{13}$ The syllable represented here as [ni] may be pronounced with some palatalisation. However, no contrast has been found between [ni] and [ni]; these syllables occur in free variation. The second author strongly prefers the former representation, so it has been adopted throughout this paper.
} 
demonstrative pronoun surfaces with a $[\mathrm{H}]$ tone. However, this is not part of the tone group being investigated; as the noun phrase forming the grammatical subject, it constitutes a separate tone group of its own, so has been excluded from the examples.

\begin{tabular}{|c|c|}
\hline $\begin{array}{c}N+C O P \\
\text { surface tones }\end{array}$ & $\begin{array}{c}N+C O P \\
\text { examples }\end{array}$ \\
\hline $11+V$ & balmil niV ' is duck' \\
\hline 1$\rfloor+1$ & ło $7 \mathrm{kr}\rfloor \mathrm{ni} / \quad$ is rib' \\
\hline$」 1+V$ & hwr Jli1 niV ' is cat' \\
\hline$\rfloor\rfloor+\Lambda$ & bi」mi」 ni/ 'is axe' \\
\hline
\end{tabular}

Table 6. Disyllabic nouns in $N+C O P$ frame

Tonal categories of disyllabic nouns are given the labels /H/, /HL/, /LH/ and $/ \mathrm{L} /$ according to their tonal realisations when appearing before the copular verb. Having determined the tonal category of a word, it may be transcribed phonemically using a superscript tone letter, e.g. $/{ }^{\mathrm{H}}$ bæ.mi/ 'duck'. The following table presents examples.

\begin{tabular}{cll}
\hline \multicolumn{1}{c}{$\begin{array}{c}\text { Tone } \\
\text { category }\end{array}$} & \multicolumn{2}{c}{ Example } \\
\hline /H/ & Hbæ.mi & 'duck' \\
/HL/ & ${ }^{H L}$ to.kr & 'rib' \\
/LH/ & LHhwr.li & 'cat' \\
/L/ & Lbi.mi & 'axe' \\
\hline
\end{tabular}

Table 7. Tonal categories of disyllabic nouns

Monosyllabic nouns spoken in isolation have only two possible surface realisations: high-falling or low-rising. Native speaker intuitions confirm these two possibilities, e.g. the nouns [jiv] 'cow' and [joV] 'sheep' have the same highfalling isolation tone, while [ts ${ }^{\mathrm{h}} \mathrm{l} /$ ] 'deer' and [zu//] 'monkey' are both realised with a low-rising tone in isolation. This is not to suggest, though, that there are only two tonal categories for monosyllabic nouns in LTD Narua. Using the same frame as for disyllabic nouns, four distinct categories also emerge for monosyllabic nouns, as exemplified in the table below. 


\begin{tabular}{|c|c|c|c|}
\hline $\begin{array}{c}\text { Isolation } \\
\text { tone }\end{array}$ & Example & $\begin{array}{c}N+C O P \\
\text { surface tones }\end{array}$ & $\begin{array}{c}N+C O P \\
\text { examples }\end{array}$ \\
\hline V & jiV 'cow' & $1+V$ & 'is cow' \\
\hline V & joV 'sheep' & $1+1$ & 'is sheep' \\
\hline$\Lambda$ & ts $\mathfrak{S}^{\mathrm{h}} æ \Lambda^{\prime}$ 'deer' & $J+V$ & tș $\left.^{\mathbf{h}} \mathfrak{e}\right\rfloor \mathbf{n i V}$ 'is deer' \\
\hline 1 & zu/ 'monkey' & \rfloor$+\Lambda$ & 'is monkey' \\
\hline
\end{tabular}

Table 8. Monosyllabic nouns in isolation and in $N+C O P$ frame

As illustrated in Table 8, when spoken in isolation the tone of a monosyllabic noun appears as a contour: either a fall or a rise. When in the frame $\mathrm{N}+\mathrm{COP}$, however, the noun surfaces with a level tone, while a contour appears on the copula. Fundamental frequency $\left(\mathrm{F}_{0}\right)$ graphs of the four sentences from which the data in Table 8 is extracted are shown below, with cop highlighted.
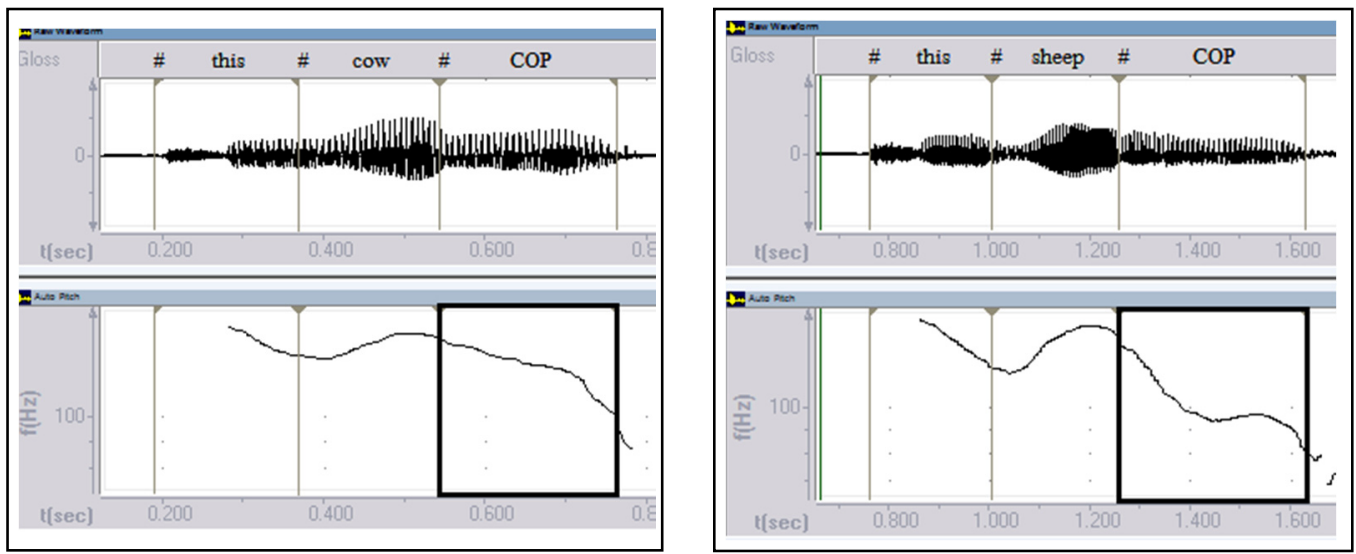

Figure 3. Fo graphs of 'DEM + cow $+C O P^{\prime}$ and 'DEM + sheep $+C O P^{\prime}$
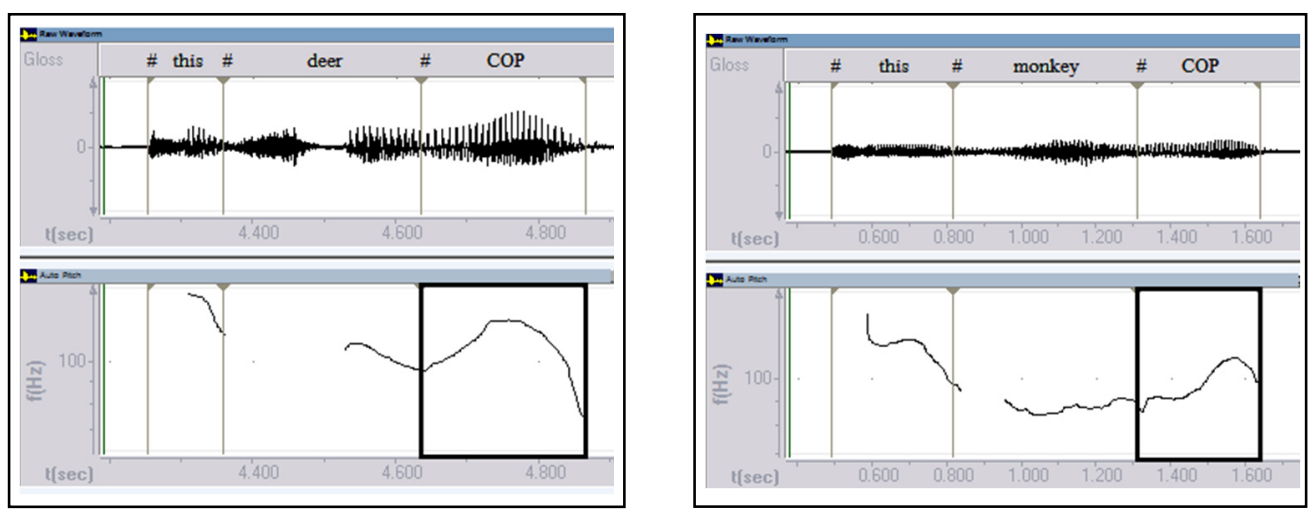

Figure 4. Fo graphs of 'DEM+deer $+C O P^{\prime}$ and 'DEM +monkey $+C O P$ '

Appropriate labels for the four categories of monosyllabic nouns was not as immediately obvious as those for disyllabic nouns. Given that the phonetic rise on the copula after 'sheep' is not as pronounced as that after 'monkey', an analysis on three tonal levels, with a contrast between [LM] and [LH], would have been possible. However, no contrast between mid and high level tones was observed, so for reasons of economy, an analysis on two tonal levels was adopted and the 
four categories were given the same labels as those of disyllabic nouns: /H/, /HL/, $/ \mathrm{LH} /$ and $/ \mathrm{L} /$ respectively.

Given that there are only two tonal realisations of monosyllabic nouns in isolation, it can be stated that the contrast between $/ \mathrm{H} /$ and $/ \mathrm{HL} /$ tonal categories is neutralised in isolation, as is that of $/ \mathrm{L} /$ and $/ \mathrm{LH} /$. It is worth noting that in two dialects of Pumi - Wadu and Niuwozi - high-level and high-falling tones are also reported as being not easily distinguishable in isolation or at the end of an intonation unit, as the high level tone is often realised as high-falling in these environments (Ding 2001:63-65, 2014:50; Daudey 2014:71). Tonal categories for LTD Narua monosyllabic nouns are summarised in the table below.

\begin{tabular}{lll}
\hline \multicolumn{1}{c}{$\begin{array}{c}\text { Tone } \\
\text { category }\end{array}$} & \multicolumn{2}{c}{ Example } \\
\hline$/ \mathrm{H} /$ & $\mathrm{H}_{\mathrm{ji}}$ & 'cow' \\
$/ \mathrm{HL} /$ & $\mathrm{HL}_{\mathrm{jo}}$ & 'sheep' \\
$/ \mathrm{LH} /$ & $\mathrm{LH}_{\mathrm{tg}} \mathrm{L}^{\mathrm{h}}$ 'deer' \\
$/ \mathrm{L} /$ & $\mathrm{L}_{\mathrm{zu}}$ & 'monkey' \\
\hline
\end{tabular}

Table 9. Tonal categories of monosyllabic nouns

Having established tonal categories for nouns, those of adjectives were comparatively straightforward to ascertain.

\section{ADJECTIVES}

LTD Narua adjectives function both as noun modifiers (attributives) and as intransitive stative verbs. As verbs they appear as predicates and, like other verbs, they may take prefixes ${ }^{14}$ such as the accomplished marker /lo-/ or the negative marker /mə-/, in which case the surface tone of the lexical item may differ from its isolation form (see Section 9). In the present section, the tonal behaviour of adjectives as attributives is presented. As attributives, their tonal behaviour is very similar to that of nouns. The majority of LTD Narua adjectives are monosyllables, so these are discussed first.

\subsection{Monosyllabic adjectives}

As an attributive, the default position for an adjective is after the noun, although it may appear in focus position before the noun for semantic reasons. Like nouns, monosyllabic adjectives appear as either high-falling or low-rising in isolation. Examples are given in the table below.

\footnotetext{
${ }^{14}$ In the case of a number of disyllabic stative verbs, /lə-/ or /mə-/ may occur as infixes, eg. $[\gamma\rfloor v u V]$ 'good looking' cf. [r」-məl-vuV] 'not good looking'. Many, but not all, of these cases can be analysed as $\mathrm{N}$-infix-V.
} 


\begin{tabular}{ccc}
\hline $\begin{array}{c}\text { Isolation } \\
\text { tone }\end{array}$ & \multicolumn{2}{c}{$\begin{array}{c}\text { Adjective } \\
\text { example }\end{array}$} \\
\hline $\mathrm{V}$ & frV & 'wide' \\
$\mathrm{V}$ & dwV & 'big' \\
$\Lambda$ & swl & 'new' \\
$\Lambda$ & toil & 'small' \\
\hline
\end{tabular}

Table 10. Examples of monosyllabic adjectives in isolation

Like nouns, four tonal categories of monosyllabic adjectives emerge when they head tone groups of two syllables or more. For the purposes of this description, the attributive particle (ATTR)/hĩ/ (similar to Chinese $d e$ 的) is chosen to exemplify adjective tone groups. The attributive particle appears as a suffix to the adjective; it does not occur in isolation in natural speech. ${ }^{15}$ Although this particle has nothing structurally in common with the copular verb in which a convenient frame for discovering tonal categories for nouns was employed, they both serve to turn a monosyllabic tone group into a disyllabic one in which there are enough tone bearing units for the tonal contrasts to unfold. In sentence (3) below, an example is given of the tonal category of the monosyllabic adjective $/ \mathrm{t}$ ci// 'small' emerging in the environment ADJ-ATTR.

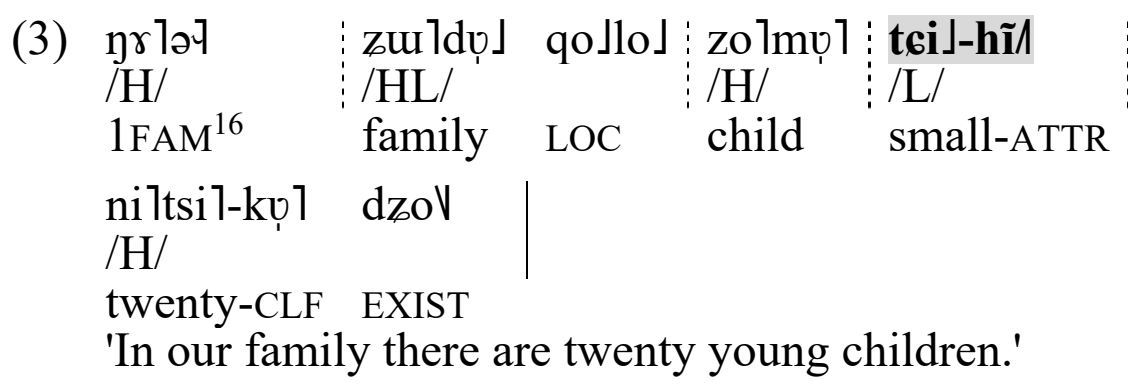

In the phrase [zolmụ1 tøi」-hĩl] 'child small-ATTR (small child)' in sentence (3), the ADJ-ATTR tone group is realised with a low tone on the adjective, and a lowrising tone on the attributive particle. Thus, the tonal category of the adjective emerges as $/ \mathrm{L} /: / \mathrm{L}$ tci/ 'small'. In the following sentence, the same noun is modified with $/{ }^{\mathrm{HL}} \mathrm{dw} /$ 'big' and the ADJ-ATTR tone group emerges as $/ \mathrm{HL} /$.

(4) zolmọ1 dul-hĩ」 $\begin{array}{lllllll}\text { /H/ } & / \mathrm{HL} / & / \mathrm{H} / & / \mathrm{H} / & \\ \text { child } & \text { big-ATTR TOP } & \text { Bima Ci'er called } \\ \text { '(My) oldest child is called Bima Ci'er.' }\end{array}$

The following table presents monosyllabic adjective categories, their isolation tones, and surface tones in the frame ADJ-ATTR, both in isolation, i.e. in clausefinal position, and in non-final position. Note that, in clause-final position, a

\footnotetext{
${ }^{15}$ Although not occurring in natural speech, when asked to provide the attributive particle in isolation form, the consultant gave it as [hĩ ].

${ }^{16}$ FAM: Family suffix
} 
contour appears on the attributive particle to complete the tone group of all tonal categories. In non-final position, however, the underlying phonological tone surfaces; no contour appears on the attributive particle except following an /L/ category adjective, where it has a low-rising tone. (See Section 8 for further discussion.)

\begin{tabular}{|c|c|c|c|c|c|c|c|}
\hline $\begin{array}{c}\text { Tone } \\
\text { category }\end{array}$ & $\begin{array}{c}\text { Isolation } \\
\text { tone }\end{array}$ & & $\begin{array}{l}\text { ective } \\
\text { mple }\end{array}$ & $\begin{array}{l}\text { ADJ-ATTR } \\
\text { tones in } \\
\text { isolation }\end{array}$ & $\begin{array}{l}\text { ADJ-ATTR } \\
\text { isolation } \\
\text { example }\end{array}$ & $\begin{array}{l}\text { ADJ-ATTR } \\
\text { tones in non- } \\
\text { final position }\end{array}$ & $\begin{array}{l}\text { ADJ-ATTR } \\
\text { non-final } \\
\text { position } \\
\text { example }\end{array}$ \\
\hline$/ \mathrm{H} /$ & V & frV & 'wide' & $1 \mathrm{~V}$ & frl-hĩV & 11 & fช 7-hĩ7 \\
\hline /HL/ & V & duv & 'big' & 11 & dul-hĩ^ & $1\rfloor$ & dư 1-hĩ 」 \\
\hline$/ \mathrm{LH} /$ & $\Lambda$ & sut & 'new' & $」 V$ & sw」-hĩ & \rfloor 1 & SuJ-hĩ \\
\hline /L/ & 1 & toil & 'small' & \rfloor$\Lambda$ & t6i」-hĩı & \rfloor$\Lambda$ & t6i」-hĩ^ \\
\hline
\end{tabular}

Table 11. Tonal categories of monosyllabic adjectives

\subsection{Polysyllabic adjectives}

Disyllabic adjectives occur less frequently, but their tonal categories are the same as those of monosyllables. The table below presents the four tonal categories and examples. Like disyllabic nouns, the tonal categories of disyllabic adjectives are apparent in isolation. Once again, the attributive particle in $/ \mathrm{L} /$ category tone groups surfaces with rising tone in non-final position, while it appears with level tone in all the other categories.

\begin{tabular}{|c|c|c|c|c|c|c|c|}
\hline $\begin{array}{l}\text { Tone } \\
\text { cat. }\end{array}$ & $\begin{array}{c}\text { Isolation } \\
\text { tones }\end{array}$ & \multicolumn{2}{|c|}{$\begin{array}{l}\text { Adjective } \\
\text { example }\end{array}$} & $\begin{array}{l}\text { ADJ-ATTR } \\
\text { tones in } \\
\text { isolation }\end{array}$ & $\begin{array}{l}\text { ADJ-ATTR } \\
\text { isolation } \\
\text { example }\end{array}$ & $\begin{array}{l}\text { ADJ-ATTR } \\
\text { tones in } \\
\text { non-final } \\
\text { position }\end{array}$ & $\begin{array}{c}\text { ADJ-ATTR } \\
\text { non-final } \\
\text { position } \\
\text { example }\end{array}$ \\
\hline$/ \mathrm{H} /$ & $7 \mathrm{~V}$ & molnaeV & ' soft' & $11+V$ & mưlnæ1-hĩ & $11+1$ & mọ ไnæ7-hĩך \\
\hline /HL/ & 11 & gọldzw/ & 'angry' & $1\rfloor+1$ & gọldzuu-hĩ」 & $1\rfloor+\rfloor$ & gọ ldzuJ-hĩ 」 \\
\hline$/ \mathrm{LH} /$ & $」 V$ & kwæJtswæV & 'crooked' & \rfloor $1+V$ & $\begin{array}{l}\text { kwæJtswæ1- } \\
\text { hĩ }\end{array}$ & \rfloor $1+1$ & $\begin{array}{l}\text { kwæJtswæ1- } \\
\text { hĩ }\end{array}$ \\
\hline /L/ & \rfloor$\Lambda$ & la」gọ & ' bent' & \rfloor$\rfloor+\Lambda$ & la」gọ-hĩ & \rfloor$\rfloor+\Lambda$ & la」gọ J-hĩ \\
\hline
\end{tabular}

Table 12. Tonal categories of disyllabic adjectives

Reduplicated adjectives of ABB pattern also occur in LTD Narua. These are analysed using the same tonal categories as nouns and mono- or disyllabic adjectives. Examples are given in the table below. 


\begin{tabular}{|c|c|c|c|c|c|c|c|}
\hline $\begin{array}{l}\text { Tone } \\
\text { cat. }\end{array}$ & $\begin{array}{c}\text { Isola- } \\
\text { tion } \\
\text { tones }\end{array}$ & $\begin{array}{l}\text { Adjec } \\
\text { exam }\end{array}$ & & $\begin{array}{c}\text { ADJ-ATTR } \\
\text { tones in } \\
\text { isolation }\end{array}$ & $\begin{array}{l}\text { ADJ-ATTR } \\
\text { isolation } \\
\text { example }\end{array}$ & $\begin{array}{c}\text { ADJ-ATTR } \\
\text { tones in } \\
\text { non-final } \\
\text { position }\end{array}$ & $\begin{array}{c}\text { ADJ-ATTR } \\
\text { non-final } \\
\text { position } \\
\text { example }\end{array}$ \\
\hline /H/ & $11 \mathrm{~V}$ & 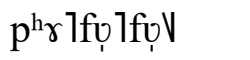 & 'spongy' & $111+V$ & $\left.\mathrm{p}^{\mathrm{h}} \gamma\right\rceil f u ̛ ̣$ ๆụ $\left.1-h \tilde{1}\right\rceil$ & $111+1$ & $\mathrm{p}^{\mathrm{h}} \gamma$ ไfụ $1 f u ̛ ̣ 1-h \tilde{1} 1$ \\
\hline /HL/ & \rfloor 11 & hũ Jdzældzæl & 'deep red' & \rfloor $1 」+\Lambda$ & $\begin{array}{l}\text { hũ Jdzældzæ」 } \\
\text {-hĩ」 }\end{array}$ & ل & $\begin{array}{l}\text { hũ Jdzældzæ」- } \\
\text { hĩ」 }\end{array}$ \\
\hline$/ \mathrm{LH} /$ & $」 7 \mathrm{~V}$ & șuJhælhæV & $\begin{array}{l}\text { 'very } \\
\text { fresh' }\end{array}$ & $」 11+V$ & $\begin{array}{l}\text { suJ Jhælhæ1- } \\
\text { hĩ }\end{array}$ & ل $11+1$ & $\begin{array}{l}\text { suJhælhæ1- } \\
\text { hĩ }\end{array}$ \\
\hline /L/ & $」 」 \Lambda$ & na」gr」gr॥ & 'dark' & \rfloor$\rfloor+\Lambda$ & na」gr」gr」-hĩn & \lrcorner$\lrcorner\rfloor+\Lambda$ & na」gr」gr」-hĩ/ \\
\hline
\end{tabular}

Table 13. Tonal categories of $A B B$ adjectives

Analyses of /H/, /LH/ and /L/ categories are unambiguous: surface tones on the adjective in ADJ-ATTR appear as [H.H.H], [L.H.H] and [L.L.L] respectively. Analysis of category /HL/ is less transparent in that the surface tones of the adjective appear as [L.H.L], rather than the expected [H.L.L]. The label /HL/ has been adopted because, where the tonal categories of monosyllabic form of these adjectives (i.e. the first syllable in $\mathrm{ABB}$ ) is known, its tonal category is $/ \mathrm{HL} /$. For instance, 'red' as a monosyllable is $/{ }^{\mathrm{HL}} \mathrm{h} \tilde{\mathrm{v}} /$, while its $\mathrm{ABB}$ counterpart is [hỗ JdzældzæJ] 'deep red'. Note, though, than an alternative pronunciation of 'spongy' was recorded - and later discarded as an error - in which the surface tones were [H.L.L]. If it is later discovered that adjectives of [H.L.L] pattern exist, a fifth tonal category for ABB adjectives will need to be added.

\section{COMPOUNDS AND CONUNDRUMS}

Given what has been seen thus far regarding tone groupings in LTD Narua, one might expect the tonal categories of compound nouns to be determined by the first component of the compound. In fact, this is often the case: $/ \mathrm{A} /+/ \mathrm{B} / \rightarrow / \mathrm{A} /$. Compare, for example, the surface realisations of 'bracelet' in the following two compounds, where isolation forms are given:

$$
\begin{aligned}
& [\mathrm{joV}]+[\mathrm{lo} d \mathrm{dzoV}] \rightarrow \text { [jollohdzoV }] \\
& \text { 'jade' 'bracelet' } \rightarrow \text { 'jade bracelet' } \\
& / \mathrm{H} /+\mathrm{LH} / \rightarrow \text { /H/ }
\end{aligned}
$$

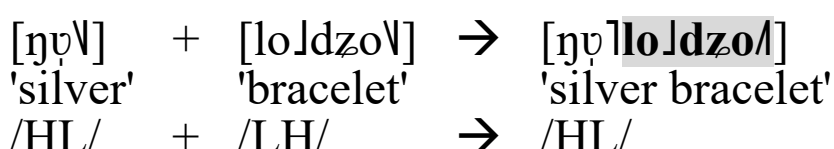

In [jolloldzoV] 'jade bracelet', the $/ \mathrm{H} /$ tone of $/ \mathrm{H} \mathrm{jo} /$ 'jade' determines the tonal category of the entire compound. 'Jade' surfaces with a simple level high tone; the high tone then spreads right to the two syllables of 'bracelet' which surface as [H.HL] when the compound is in isolation, or as $[\mathrm{H} . \mathrm{H}]$ in non-clause-final position. In [yvillo Jdzo/] 'silver bracelet', it is the /HL/ tonal category of $/{ }^{H L} \mathrm{yv} /$ 
'silver' that determines the tonal category of the compound. In this case, 'silver' receives a high tone, followed by a low tone which appears on the first syllable of 'bracelet' and spreads to the right. In isolation form, a final rise is added to the last syllable of the tone group, resulting in 'bracelet' surfacing as [L.LH].

Further examples of tonal categories of compound nouns being determined by that of the first element are presented in Table 14 below. In these examples, as in those seen above, the entire compound takes the tonal category of the first element. These compounds also provide examples of tri- and quadri-syllabic nouns in isolation form. 


\begin{tabular}{|c|c|c|c|c|c|c|}
\hline \multirow{2}{*}{$\begin{array}{l}\text { Tone } \\
\text { cat } 1\end{array}$} & \multirow{2}{*}{$\begin{array}{l}\text { Tone } \\
\text { cat } 2 \\
\text { /H/ }\end{array}$} & \multicolumn{2}{|c|}{$\begin{array}{l}\text { Isolation tones } \\
\text { of components }\end{array}$} & $\begin{array}{c}\text { Tone cat. } \\
\text { of } \\
\text { compound }\end{array}$ & \multicolumn{2}{|c|}{$\begin{array}{l}\text { Isolation tones } \\
\text { of compound }\end{array}$} \\
\hline & & jiV + seV & 'cow' + 'meat' & \multirow{8}{*}{$/ \mathrm{H} /$} & ji $\rceil_{s e V}$ & 'beef' \\
\hline \multirow{7}{*}{$/ \mathrm{H} /$} & & polgọ $V+$ haV & 'corn' + 'food' & & polgọ lhaV & 'corn porridge' \\
\hline & /HL/ & mỵ $\left.1^{17}\right\rfloor+$ grlla/ & 'sky' + 'god' & & mỵlgrllaV & 'sky god' \\
\hline & & $\operatorname{la}^{\mathrm{th}} \mathrm{aV}+\operatorname{diV}$ & $\begin{array}{l}\text { 'Lata (clan)' + } \\
\text { 'land' }\end{array}$ & & lalthaldiV & 'Lataddi (place)' \\
\hline & /LH/ & $\mathrm{jiV}+\mathrm{q}^{\mathrm{h}} \mathrm{y} \Lambda$ & 'cow' + 'horn' & & ji $7 q^{h} y V$ & 'cow horn' \\
\hline & & ni lzoV + kọ & 'fish' + 'rind' & & ni lzolkọV & 'fish scales' \\
\hline & \multirow[t]{2}{*}{ /L/ } & brV + mol & 'Pumi' + 'old' & & brlmoV & $\begin{array}{l}\text { 'old Pumi } \\
\text { person' }\end{array}$ \\
\hline & & jil + yu 1 & 'cow' + 'skin' & & jilyu V & 'cow skin' \\
\hline \multirow{7}{*}{ /HL/ } & $/ \mathrm{H} /$ & joV + hũV & 'sheep' + 'hair' & \multirow{7}{*}{ /HL/ } & jolhũ/ & 'wool' \\
\hline & & dzulbo/ + seV & 'wild pig' + 'meat' & & dzuilbo」sel & 'wild pork' \\
\hline & /HL/ & воV + grlla凡 & 'mountain' + 'god' & & во lgrلla/ & 'mountain god' \\
\hline & /LH/ & $\mathrm{joV}+\mathrm{q}^{\mathrm{h}} \mathrm{y} \Lambda$ & 'sheep' + 'horn' & & jolq ${ }^{h}$ 凡 & 'sheep horn' \\
\hline & \multirow{3}{*}{ /L/ } & nọ $V+10\rfloor d z o V$ & 'silver' + 'bracelet' & & jụ $110 ل \mathrm{~d} z \mathrm{O} /$ & 'silver bracelet' \\
\hline & & joV + yu/ & 'sheep' + 'skin' & & jo lyw/ & 'sheepskin' \\
\hline & & bỵV + tswæ」zuu/ & 'yak' + 'reins' & & byltswæJzuu/ & 'yak reins' \\
\hline \multirow{6}{*}{ /LH/ } & \multirow[t]{2}{*}{$/ \mathrm{H} /$} & $\operatorname{ts}^{\mathrm{h}} æ /+\mathrm{seV}$ & 'deer' + 'meat' & \multirow{6}{*}{ /LH/ } & $\left.\operatorname{ts}^{\mathrm{h}} \mathfrak{x}\right\rfloor_{\mathrm{SeV}}$ & 'venison' \\
\hline & & $\begin{array}{l}\text { cul Jts }{ }^{\mathrm{h}} w æ V+ \\
\text { haV }\end{array}$ & 'rice' + 'food' & & cuJts ${ }^{h}$ wælhaV & 'rice (cooked)' \\
\hline & /HL/ & $\operatorname{tg} \mathfrak{s}^{\mathrm{h}} \boldsymbol{\Lambda}+\operatorname{diV}$ & 'deer' + 'land' & & $\operatorname{ts}^{\mathrm{h}} æ J \mathrm{diV}$ & 'deer land' \\
\hline & \multirow[t]{2}{*}{ /LH/ } & $\mathrm{ts}^{\mathrm{h}} \mathfrak{x} \Lambda+\mathrm{q}^{\mathrm{h}} \mathrm{\gamma} \Lambda$ & 'deer' + 'horn' & & $\operatorname{ts}^{\mathrm{h}} \mathfrak{J} \mathrm{q}^{\mathrm{h}} \mathrm{Y} V$ & 'deer antler' \\
\hline & & 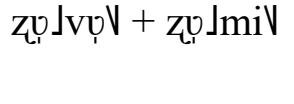 & $\begin{array}{l}\text { 'grandson' + } \\
\text { 'granddaughter' }\end{array}$ & & 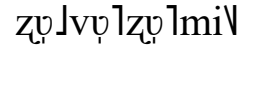 & 'grandchildren' \\
\hline & /L/ & ts ${ }^{\mathrm{h}} \mathfrak{l}$ + yu/ & 'deer' + 'skin' & & ts ${ }^{\mathrm{h}} \mathfrak{\text { J JuUV }}$ & 'deer skin' \\
\hline \multirow{7}{*}{ /L/ } & \multirow[t]{2}{*}{$/ \mathrm{H} /$} & mọ $1+$ zol & 'female' + 'child' & \multirow{7}{*}{ /L/ } & mụ」zo/ & 'girl, daughter' \\
\hline & & vọ」dze/ + hợV & 'bird' + 'hair' & & vọ」dze Jhỡ & 'feather' \\
\hline & /HL/ & cil + dzulV & 'lake' + 'water' & & ci」dzul & 'lake water' \\
\hline & & vọ Jdze $\Lambda+\mathrm{k}^{\mathrm{h}} \underset{\mathrm{v}}{\mathrm{V}} \mathrm{V}$ & 'bird' + 'nest & & vọ Jdze Jk ${ }^{\mathrm{h}}{ }_{\varphi} /$ & 'bird's nest' \\
\hline & \multirow[t]{2}{*}{ /LH/ } & li $\Lambda+q^{h} w \gamma \Lambda$ & 'tea' + 'bowl' & & li Jqu $q^{\mathrm{h}} \mathrm{r} /$ & 'tea bowl' \\
\hline & & 6uJtcil + kט̣ & 'plum' + 'rind' & & GuI Jt6iJkọ/ & 'plum skin' \\
\hline & /L/ & $\mathrm{na} \Lambda+\mathrm{m} \cup \mathrm{A}$ & 'Na' + 'girl' & & na」mọı & 'Na girl' \\
\hline
\end{tabular}

Table 14. Examples of tonal categories of compound nouns

However, as alluded to in the introduction, not all tonal categories of LTD Narua compound nouns are determined by that of the first component. In a small

\footnotetext{
17 The phoneme transcribed here as $/ \mathrm{y} /$ is articulated with very close, very spread lips and appears to be similar to that described by Lidz (2010:40) in Luoshui Narua. Note that this phoneme is distinct from that transcribed as / $v /$ in LTD Narua.
} 
number of compounds, the tones of both components are retained. For example:

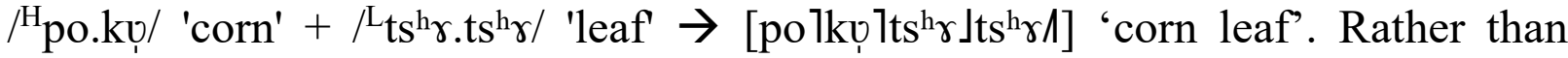
create further tonal categories to accommodate such forms, these compounds are analysed as containing two tone groups: $/ \mathrm{A} / \mathrm{+} / \mathrm{B} / \rightarrow / \mathrm{A}+\mathrm{B} /$.

A further permutation involves compounds in which, although the surface tone of the first component remains unchanged, the compound noun does not necessarily emerge as belonging to the same tonal category as the first component. Take, for example, compounds in which the first component is 'pig'. In isolation ${ }_{2}$ this item is [bo/], and in the $\mathrm{N}^{+} \mathrm{COP}$ frame it emerges as $/ \mathrm{LH} /$ i.e. [bo niV] 'pig COP (is pig)'. Some compounds yield the expected /LH/ tone, as exemplified in Table 15.

\begin{tabular}{|c|c|c|c|c|c|c|}
\hline $\begin{array}{l}\text { Component } 1 \\
\text { isolation tone }\end{array}$ & & $\begin{array}{l}\text { iponent } 2 \\
\text { ation tone }\end{array}$ & & $\begin{array}{r}\text { Comp } \\
\text { isolatio }\end{array}$ & tones & $\begin{array}{c}\text { Tone cat. of } \\
\text { compound }\end{array}$ \\
\hline bol' 'pig' & + bọV & 'animal pen' & $\rightarrow$ & boJbụV & 'nio nen' & /LH/ \\
\hline 'deer' & $+\tilde{\mathrm{Y}} V$ & & $\rightarrow$ & & & /LH/ \\
\hline bo/' & + уш/ & 'skin' & $\rightarrow$ & bo」yuil & 'pig s & /LH/ \\
\hline 'pig' & $+\mathrm{dzw} æ V$ & 'tusk' & $\rightarrow$ & bo」dzwwæl & 'pig tusk' & /LH/ \\
\hline
\end{tabular}

Table 15. Compounds with 'pig' where tonal category is /LH/

In these cases, $/ \mathrm{A} / \mathrm{+} / \mathrm{B} / \rightarrow / \mathrm{A} /$. Other compounds, however, emerge as tonal category /L/, such as those shown in Table 16.

\begin{tabular}{|c|c|c|c|c|c|}
\hline $\begin{array}{l}\text { Component } 1 \\
\text { isolation tone }\end{array}$ & & $\begin{array}{l}\text { Component } 2 \\
\text { isolation tone }\end{array}$ & & $\begin{array}{l}\text { Compound } \\
\text { isolation tones }\end{array}$ & $\begin{array}{l}\text { Tone cat. of } \\
\text { compound }\end{array}$ \\
\hline bo/' 'pig' & & seV 'meat' & & boلsel 'pork' & \\
\hline 'deer' & + & 'hair' & $\rightarrow$ & & $/ \mathrm{L} /$ \\
\hline bol' & + & 'food' & $\rightarrow$ & 'pig food' & /L/ \\
\hline
\end{tabular}

Table 16. Compounds with 'pig' where tonal category is /L/

That these compounds are not of the $/ \mathrm{A} /+\mathrm{B} / \rightarrow / \mathrm{A}+\mathrm{B} /$ type is evidenced by the fact that $/ \mathrm{H} /$ category nouns $/{ }^{\mathrm{H}} \mathrm{se} /{ }^{\prime}$ meat', $/{ }^{\mathrm{H}}$ hũ/ 'hair', and $/{ }^{\mathrm{H}} \mathrm{ha} /$ 'food' all emerge with low-rising surface tones. In these cases, $/ \mathrm{A} /+/ \mathrm{B} / \rightarrow / \mathrm{C} /$. While the surface tone of the first syllable in these compounds is consistently [L] and the tones of the resulting compounds still fit into one of the four existing tonal categories for nouns, it is not clear why a variation between $/ \mathrm{LH} /$ and /L/ forms exists in compounds where the first morpheme is 'pig'. It is possible that the presence of these variants may necessitate the addition of a fifth tonal category for nouns such as these.

There remain a further number of compounds, again neither of the $/ \mathrm{A} /+\mathrm{B} / \rightarrow / \mathrm{A} /$ type nor the $/ \mathrm{A} /+\mathrm{B} / \rightarrow / \mathrm{A}+\mathrm{B} /$ type, in which it is the surface tone of the first syllable that differs from its simple form. For instance, $/{ }^{H} \mathrm{la} /{ }^{\prime}$ 'tiger' and $/ \mathrm{H} \tilde{\mathrm{v}} /$ 'bone' combine to form [la following table gives further examples. 


\begin{tabular}{|c|c|c|c|c|}
\hline $\begin{array}{l}\text { Tone } \\
\text { cat } 1\end{array}$ & $\begin{array}{l}\text { Tone } \\
\text { cat } 2\end{array}$ & $\begin{array}{l}\text { Isolation tones } \\
\text { of components }\end{array}$ & $\begin{array}{l}\text { Tone cat. of } \\
\text { compound }\end{array}$ & $\begin{array}{c}\text { Isolation tones } \\
\text { of compound }\end{array}$ \\
\hline$/ \mathrm{H} /$ & $/ \mathrm{H} /$ & 'door' + 'mouth' & $/ \mathrm{L} /$ & 'doorway' \\
\hline$/ \mathrm{H} /$ & $/ \mathrm{H} /$ & 'tiger' + 'bone' & /LH/ & 'tiger bone' \\
\hline$/ \mathrm{H} /$ & /H/ & 'milk' + 'hard' & /LH/ & 'yoghurt' \\
\hline$/ \mathrm{H} /$ & $/ \mathrm{LH} /$ & 'alcohol' + 'bowl' & $/ \mathrm{LH} /$ & 'alcohol bowl' \\
\hline$/ \mathrm{H} /$ & /L/ & 'cow' + 'female' & $/ \mathrm{L} /$ & 'cow (fem.)' \\
\hline
\end{tabular}

Table 17. Examples of compound nouns where surface tone of first component changes

Although the above table is not an exhaustive list, the trend indicated by the examples is accurate. That is, the majority of instances in which the tone of the first component surfaces differently in compound form than in simple form involve $[\mathrm{H}]$ surfacing as $[\mathrm{L}]$ rather than the other way around. These compounds which are irregular with respect to the currently productive compound patterns may, in fact, turn out to be indicative of earlier forms. As noted above, the resulting compounds still fit into the four existing tonal categories for nouns.

\section{TONE GROUPS AND TONE GROUP BOUNDARIES}

Having examined the tonal behaviour of nouns and adjectives both in isolation and in frames, and before discussing that of verbs, the subject of tone groups and tone group boundaries is now considered. Thus far, it has been seen that the surface tone of the copula and the possessive particle are determined by the preceding noun, the surface tone of the attributive particle depends on the preceding adjective, and the tonal category of many compounds is determined by that of the first element. These are all examples of tone groups.

\subsection{Longer noun phrases}

Longer tone groups headed by a noun occur in phrases containing N+DEM+CLF 'this (noun)' or N+one-CLF 'a (noun)'. The following sentences give examples of such phrases in each of the four tonal categories. Note that in sentences (6) and (7), the tone group also incorporates the verb.

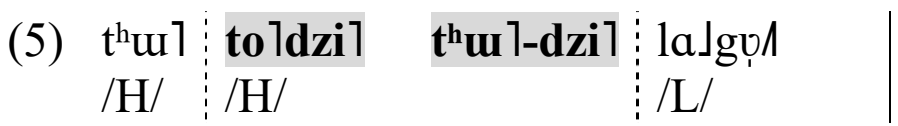

DEM pine tree DEM-CLF be crooked

'This tree is crooked'

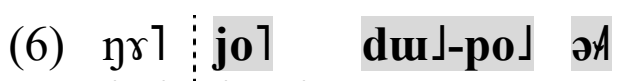

/H/ $/ \mathrm{HL} /$

1SG sheep one-CLF look at

'I look at a sheep.'

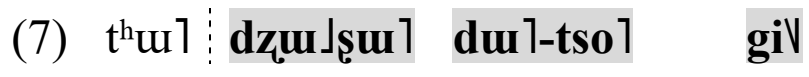


/H/ $:$ /LH/

3SG chopstick one-CLF.PAIR give

'He gave (me) a pair of chopsticks.'

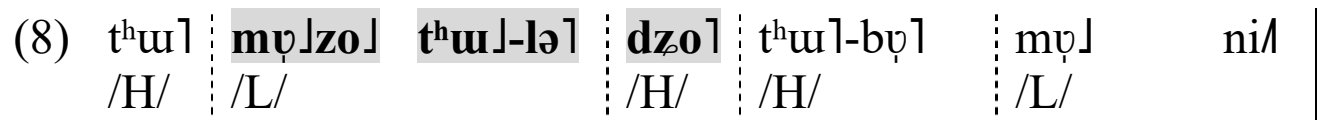
DEM girl DEM-CLF TOP 3SG-POSS daughter COP
'This girl is her daughter.'

A noun may also head the tonal category of a phrase in which a number appears, as exemplified in the following elicited sentences. Once again, in these sentences the tone group headed by the noun also incorporates the verb.

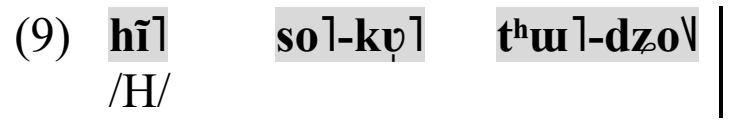

person three-CLF DUR-EXIST

'There are three people.'

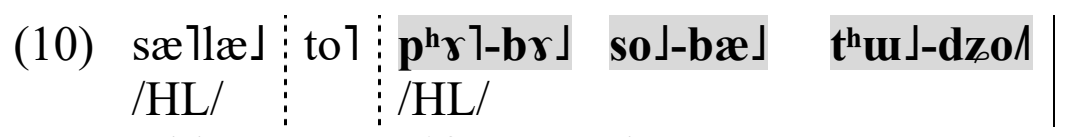
table on gift three-CLF DUR-EXIST

'On the table there are three gifts.'

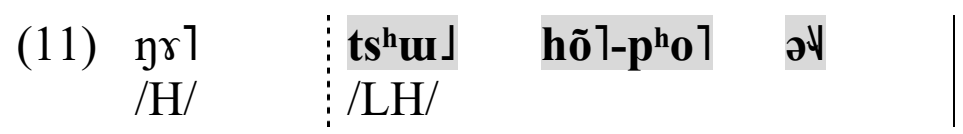
1SG goat eight-CLF look at
'I look at eight goats.'

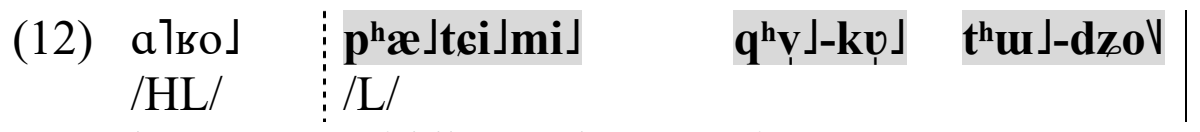
home middle-aged man six-CLF DUR-EXIST
'At home there are six middle-aged men.'

The placement of tone group breaks is often syntactically motivated, at least in part. Data presented so far demonstrates that, in a sentence with both subject and object, a tone group break occurs between the two. Where there is no grammatical object, a tone group break often occurs after the subject. There are, however, exceptions to this, such as when the sentence has an existential verb, e.g. sentence (9) above. A verb may also be included in a tone group headed by an object noun (see Section 9). Conversely, a noun phrase is not necessarily comprised of only one tone group:

- the demonstrative pronoun occurring before a noun forms a tone group on its own (e.g. sentence (5));

- a tone group break occurs after the possessive particle (e.g. sentence (1)); 
- and if the noun is modified with ADJ-ATTR, there is a tone group break between the noun and the adjective (e.g. sentence (3)).

On the other hand, semantic motivations for the placement of tone group boundaries also exist. This is also the case in PJ Narua, where it is reported that there is often more than one option for the placement of tone group boundaries within an utterance; choice of boundary placement depends on factors pertaining to information structure, such as phrasing and prominence (Michaud 2015:1). Although this phenomenon has yet to be studied in detailed for LTD Narua, the following section illustrates a case of semantically motivated tone group boundary placement.

\subsection{Tone group break before emphasised number}

While noun+number-classifier ( $\mathrm{N}+\mathrm{NUM}-\mathrm{CLF}$ ) may form a single tone group, as seen in sentences (9)-(12) in Section 7.1 above, this is often not the case. If a speaker wishes to emphasise the number rather than the noun in a noun phrase, a tone group break occurs after the noun. A new tone group headed by the number then follows. In this case, where prominence is given to the number, the placement of the tone group break is semantically motivated. Such NUM-CLF tone groups may be described using the same four tonal categories as nouns and adjectives. Consider the following example:

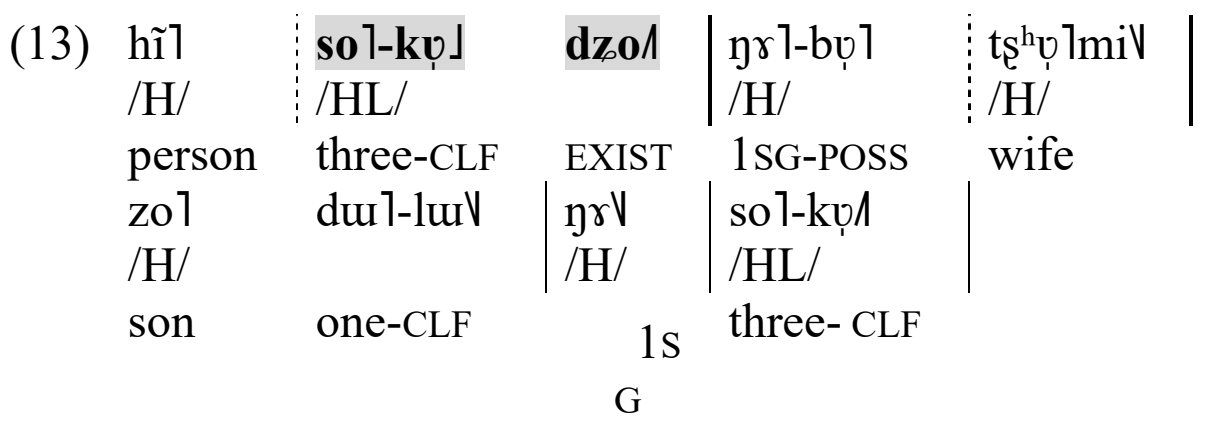

'There are three people: my wife, a son, me, three (of us).'

In the first clause of sentence (13), N+NUM-CLF comprises two distinct tone groups. Here, $/{ }^{\mathrm{H}} \mathrm{hi} /$ 'person' forms a tone group on its own, followed by a break. A new tone group of category /HL/ headed by the number 'three' then appears: [solkọ」dzoJ] 'three-CLF EXIST'. The speaker is emphasising the fact that there are three people in his family. This contrasts with the tonal realisations of the same $\mathrm{N}+\mathrm{NUM}-\mathrm{CLF}$ seen in sentence (9), where the number is not being emphasised and the entire phrase, including the verb, is one /H/ category tone group: [hĩ 1 sol-kụ] $t^{\text {th }}$ ul-dzoV] 'person three-CLF DUR-EXIST'. The following sentence provides another example of a noun phrase in which a tone group break occurs between the noun and the number. 


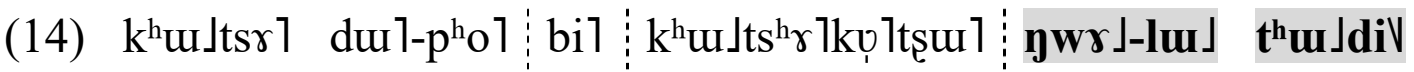 \begin{tabular}{l|l:llll} 
/LH/ & $/ \mathrm{H} / \mathrm{LH} /$ & $/ \mathrm{L} /$
\end{tabular} foot one-CLF on toenail five-CLF DUR-EXIST 'There are five toenails on a foot.'

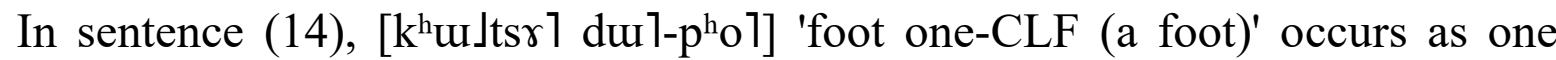

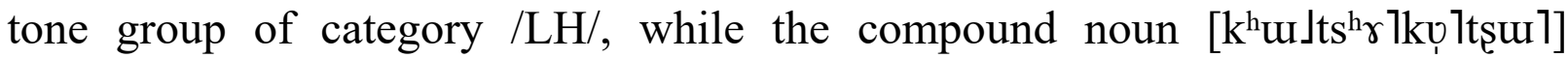
'toenail' comprises a /LH/ tone group on its own. A break occurs before the number [ywr/] 'five' which heads a /L/ category tone group: [ywrJ-luJ th $\mathrm{w} J$ div] 'five-clf DUR-EXIST (there are five)'. In this case, the number five is given prominence.

\section{TONE SPREADING}

In the tone groups that have been analysed to date, where the group is headed by a noun, an adjective, or a number, it is the left-most lexical item that determines the category of the tone group, and any tone spreading occurs to the right. Sentences (5)-(12), seen in Section 7, provided examples of tone spreading in longer noun phrases of each of the four tonal categories. Observations for tone groups headed by a noun, adjective or number (in NUM-CLF constructions) are summarised as follows.

For tone groups whose leftmost lexical item is $/ \mathrm{H} /$ category, $[\mathrm{H}]$ is spread across the entire group. In clause final position, a falling contour appears on the final syllable. In all other environments, however, there is no contour and a level $[\mathrm{H}]$ tone appears throughout the tone group. For this reason, the falling tone, although part of the surface phonology, is not considered part of the underlying tonal makeup of $/ \mathrm{H} /$ category tone groups. Tone groups comprised of only $[\mathrm{H}]$ occur frequently in LTD Narua. Tone spreading for $/ \mathrm{H} /$ category tone groups of one, two and three syllables is depicted in Figure 5, where $\sigma$ represents a syllable and a pecked line represents tone spreading.
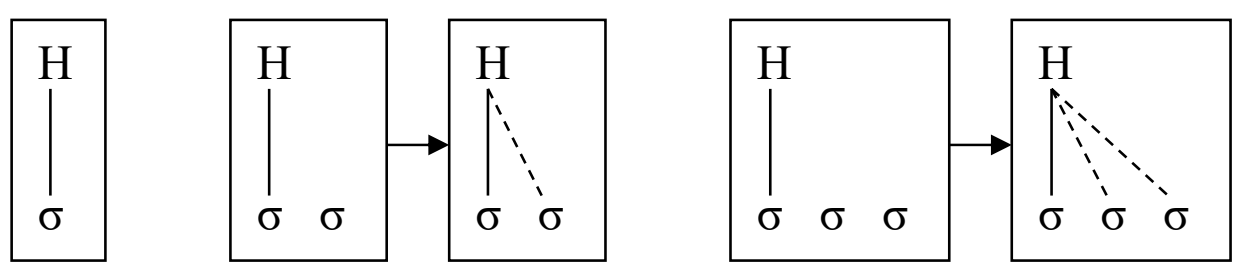

Figure 5. Tone spreading in /H/ category tone groups of one, two and three syllables

Nouns and adjectives of tonal category /HL/ surface as a high-falling tone on monosyllables. In tone groups of two syllables or more, the first syllable is realised with a level $[\mathrm{H}]$ tone, then [L] surfaces on the second syllable and spreads to the right across the remainder of the tone group. In clause final position, a rising contour may appear on the final syllable. Otherwise there is no contour; the clause final contour is not part of the underlying tonal makeup of $/ \mathrm{HL} /$ tone groups. At an underlying level, /HL/ monosyllables are analysed as two level 
tones - $[\mathrm{L}]$ and $[\mathrm{H}]$ - appearing on a single tone-bearing unit. Tone spreading for /HL/ tone groups of one, two and three syllables is depicted in Figure 6.
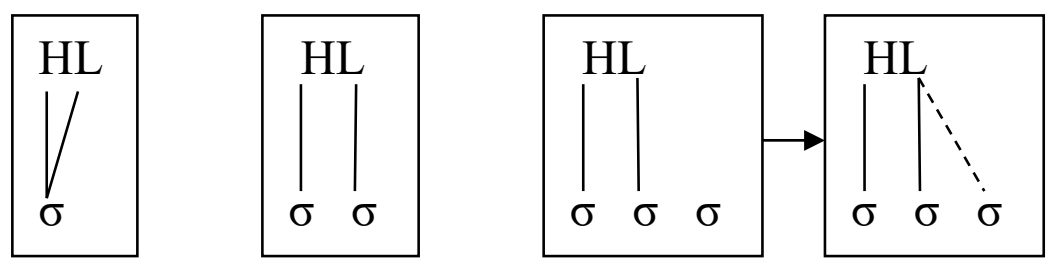

Figure 6. Tone spreading in /HL/ category tone groups of one, two and three syllables

In tonal groups of category / $\mathrm{LH} /$, monosyllabic nouns and adjectives surface with a rising tone. In polysyllabic tone groups, however, a level [L] tone appears on the first syllable and $[\mathrm{H}]$ surfaces on the second syllable and spreads to the right across any remaining syllables. The final syllable in a clause surfaces as a fall, but mid-clause appears as a level high tone. /LH/ monosyllables are analysed, not as contours, but as two level tones - $[\mathrm{L}]$ and $[\mathrm{H}]$ - appearing on a single tone bearing unit. Tone spreading in / $\mathrm{LH} /$ category tone groups is represented in Figure 7.
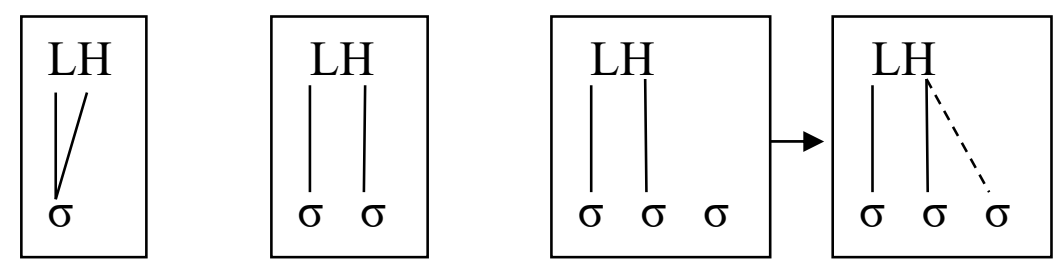

Figure 7. Tone spreading in /LH/ category tone groups of one, two and three syllables

\section{1. /L/ category tone spreading}

Tonal category /L/ is more complex. In isolation, /L/ category monosyllables surface with low-rising tone, i.e. [LH]. In the case of polysyllabic nouns and adjectives, and in ADJ-ATTR and O+V constructions (to be seen in Section 9), the low tone spreads to the right, with an obligatory rise appearing on the last syllable. The rise in $/ \mathrm{L} /$ tone groups is the only contour that appears in the middle of a clause; it is analysed as being part of the underlying tonal system of LTD Narua. Its presence normally signals the end of a tone group. Figure 8 depicts /L/ category tone spreading for one, two and three syllable tone groups.
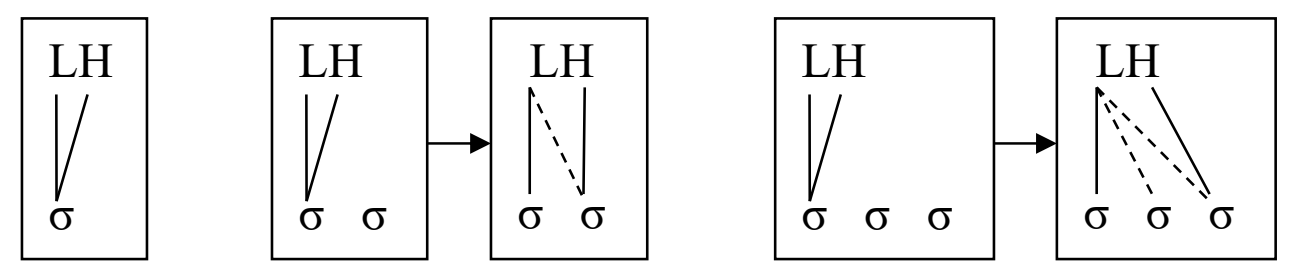

Figure 8. Tone spreading in /L/ category tone groups of one, two and three syllables

In longer /L/ category tone groups, [L] is pushed out to all but the final syllable or, in certain syntactic constructions, to the penultimate syllable, after which a high tone surfaces. The following sentences give examples of surface $[\mathrm{H}]$ 
in /L/ category tone groups. Note that in sentence (15) the high tone surfaces on the final syllable, i.e. on the verb stem following the durative prefix, followed by a clause-final fall.

(15)

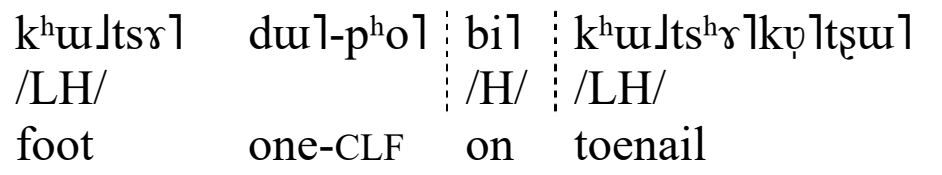

'There are five toenails on a foot.'

\begin{tabular}{|c|c|c|c|}
\hline $\begin{array}{l}\text { dze Jmi Jbọ Jluu } 1 \\
\text { /L/ }\end{array}$ & $\begin{array}{l}\mathrm{dzo} 1 \\
/ \mathrm{H} /\end{array}$ & $\begin{array}{l}\text { dze Jmi J-bv1 } \\
/ \mathrm{L} /\end{array}$ & $\begin{array}{l}\left.\text { zullq }{ }^{\mathrm{h}} \mathrm{wr}\right\rfloor \\
/ \mathrm{HL} /\end{array}$ \\
\hline $\begin{array}{l}\text { b/ } \\
\text { beehive }\end{array}$ & TOP & bee POSS & house \\
\hline
\end{tabular}

'(A) beehive is (a) bee's house.'

\begin{tabular}{|c|c|c|c|c|c|c|}
\hline $\begin{array}{l}\mathrm{th}^{\mathrm{h}} \mathrm{ul} \\
/ \mathrm{H} /\end{array}$ & $\begin{array}{l}\text { müJzo」 } \\
/ \mathrm{L} /\end{array}$ & $\mathrm{t}^{\mathrm{h}} u \mathbf{u}$-lut & $\begin{array}{l}\mathrm{d} \text { mo } 1 \\
/ \mathrm{H} /\end{array}$ & $\begin{array}{l}\mathfrak{t h}^{\mathrm{h}} \mathrm{u} 1-\mathrm{b} v \mathbf{1} \\
/ \mathrm{H} /\end{array}$ & mọ」 & ni/ \\
\hline DEM & girl & DEM-CLF & TOP & 3SG-POSS & daughter & $\mathrm{COP}$ \\
\hline
\end{tabular}

Based on the evidence it is concluded that, in LTD Narua, tone groups comprised of only [L] are prohibited. The same is true in PJ Narua (Michaud 2008).

Finally, the most elusive aspect of the LTD Narua tonal system is discussed: verbs.

\section{VERBS, FINALLY}

Tonal categories of LTD Narua verbs are far less transparent than nouns, adjectives, or number-classifier constructions. Occurring clause-finally in a SOV grammatical system, the surface tone of verbs tends to be influenced by the preceding phonological environment, whether by a noun, adjective, or numberheaded tone group, as has been seen in numerous examples thus far, or by a verbal prefix. This system appears to have similarities with that of Shixing (mentioned above), where tone derivation of polysyllabic "phonological words" is determined, among other factors, by "the presence or absence of lexical tone on the initial element of the phonological word" and where toneless elements include prefixes (Chirkova \& Michaud 2009:1).

Most LTD Narua verb roots are monosyllables and, like other word classes, surface as either high-falling or low-rising in isolation. In natural speech, however, verbs occur in isolation infrequently, so observing or eliciting isolation forms is not always a straightforward matter.

\subsection{Object + Verb constructions}

Where an object+verb $(\mathrm{O}+\mathrm{V})$ construction occurs without the presence of a verb prefix such as /æ-/ 'Q' or /mə-/ 'NEG', the tonal category of the preceding noun 
often determines that of the entire phrase. Compare, for example, the surface tones of the verb in these two phrases:

[zul t th $\mathbf{t}^{\mathrm{h}} \mathbf{\mathrm { V }}$ ] 'alcohol drink (drink alcohol)'

[li」 $\mathbf{t}^{\mathrm{h}} \mathbf{w} \mathbf{M}$ ] 'tea drink (drink tea)'

In the first case, $/{ }^{\mathrm{H}} \mathrm{zu} / /$ 'alcohol' is a $/ \mathrm{H} /$ category noun, and the tone on $\left[\mathrm{t}^{\mathrm{h}} \mathrm{w}\right]$ 'drink' surfaces with a high-falling tone in isolation form. In the second, /Lli/ 'tea' is a $/ \mathrm{L} /$ category noun, and the verb surfaces with a low-rising tone.

The sentences below, extracted from the text Daily Life (see appendix), present examples of the surface tone of the verbs 'cook' - which appears in isolation form as [goll] - and 'eat' - which appears in isolation form as [dzul] - being determined by the tonal category of the preceding noun.

(18)

$\begin{array}{ll:l}\mathrm{t}^{\mathrm{h}} \mathrm{u} \text { lgil } & \text { nul } & \mathrm{d} z 01 \\ / \mathrm{H} / & & / \mathrm{H} / \\ \text { next } & \text { ABL }{ }^{18} & \text { TOP } \\ \left.\text { ts }^{\mathrm{h}} \mathrm{\omega}\right\rfloor & \text { gol } & \text { so } 1\end{array}$

/LH/

breakfast $\operatorname{tss}^{\mathrm{h}}{ }_{\mathrm{U}} \mathrm{J}$

/LH/

breakfast cook

'Next (we) cook breakfast, cook breakfast to eat.'

$\begin{array}{ll:l:lll:ll}\mathrm{ts}^{\mathrm{h}} \gamma 1 & \text { nul } & \mathrm{d} z 01 & \text { zo」 } & \text { go」 } & \text { so } 1 & \text { zo」 } & \text { dzu/ } \\ / \mathrm{H} / & / \mathrm{H} / & / \mathrm{L} / & & & / \mathrm{L} / & \end{array}$

there ABL TOP lunch cook in order to lunch eat 'Next (we) cook lunch to eat lunch.'

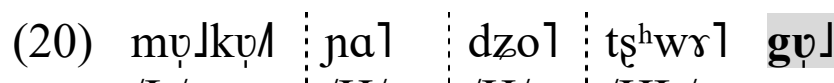 /L/ $/ \mathrm{H} / \mathrm{H} / \mathrm{H} / \mathrm{HL} / \mathrm{HL}$ evening when TOP dinner cook dinner eat 'When it's evening, (we) cook dinner (and) eat dinner.'

In the /LH/ tone groups headed by 'breakfast', the verb 'cook' surfaces as $[\mathrm{H}]$ or [HL]. Where / ${ }^{\mathrm{zo} /} /$ 'lunch' heads the tone groups, the verbs 'cook' and 'eat' surface as $[\mathrm{L}]$ or $[\mathrm{LH}]$, depending on their position in the sentence. The same verbs surface as [L] when the tone group is headed by $/{ }^{H L} t_{s^{h}}{ }^{\mathrm{w}} \mathrm{r} /$ 'dinner'.

Further examples showing surface tones of $\mathrm{O}+\mathrm{V}$ constructions being determined by the tonal category of the noun are given in the table below. Note that in the leftmost column, it is the isolation forms of the verbs that are given, i.e. $V$ or $\Lambda$. This is, however, by no means to suggest that there are only two tonal categories for verbs in LTD Narua.

${ }^{18}$ ABL: Ablative marker 


\begin{tabular}{|c|c|c|c|c|c|}
\hline & $\begin{array}{l}\text { b isolation } \\
\text { form }\end{array}$ & $\begin{array}{r}O b \\
\text { with to }\end{array}$ & $\begin{array}{l}\text { ject noun } \\
\text { nal category }\end{array}$ & $\begin{array}{l}\text { Obje } \\
\text { surfa }\end{array}$ & $\begin{array}{l}t+\text { Verb } \\
\text { e tones }\end{array}$ \\
\hline$\overline{\mathrm{dzu}}$ & 'eat' & ${ }^{\mathrm{H}_{\mathrm{ha}}}$ & 'food, grain' & ha1 dzuVV & 'eat food' \\
\hline & & ${ }^{\mathrm{LH}} \mathrm{mo}$ & 'mushroom' & mo」dzul & 'eat mushroom' \\
\hline & & $\mathrm{L}_{\mathrm{ZO}}$ & 'midday meal' & zo」dzu/ & 'eat lunch' \\
\hline dziV & 'sit' & ${ }^{\mathrm{H}} \mathrm{tS}^{\mathrm{h}} \mathrm{e} . \mathrm{tsu}$ & 'car' & ts ${ }^{\mathrm{h}} \mathrm{e}$ tsuil dziV & 'go by car' \\
\hline & & ${ }^{H L} k^{h} \underline{v}$ & 'nest' & $\mathrm{k}^{\mathrm{h}} \mathrm{v} 1 \mathrm{dzi} /$ & $\begin{array}{l}\text { 'rest for a month } \\
\text { after childbirth' }\end{array}$ \\
\hline & & $\mathrm{L}_{\mathrm{Zu}} \cdot \mathrm{gu}$ & 'boat' & zu」gọ dzi/ & 'go by boat' \\
\hline nov & 'bury' & $\mathrm{H}_{\mathrm{mo}}$ & 'corpse' & mol nov & 'bury corpse' \\
\hline & & $\mathrm{HL}_{\text {jo }}$ & 'sheep' & jol nṿl & 'bury sheep' \\
\hline seV & 'look for' & ${ }^{\mathrm{H}} \mathrm{bæ.mi}$ & 'duck' & bælmil seV & 'look for duck' \\
\hline & & ${ }^{\mathrm{LH}} \mathrm{mo}$ & 'mushroom' & mo」seV & $\begin{array}{l}\text { 'look for } \\
\text { mushroom' }\end{array}$ \\
\hline$t^{\mathrm{h}} u \mathrm{~V}$ & 'drink' & $\mathrm{H}_{\mathrm{Z} U \mathrm{U}}$ & 'alcohol' & zul thuV & 'drink alcohol' \\
\hline & & ${ }^{\mathrm{L}} \mathrm{li}$ & 'tea' & li」 $\mathbf{t}^{\mathrm{t}} \mathbf{u} / \mathbf{A}$ & 'drink tea' \\
\hline t6 ${ }^{\mathrm{hiV}}$ & 'sell' & ${ }^{\mathrm{H}} \mathrm{ha}$ & 'food, grain' & hal to ${ }^{\text {hiV }}$ & 'sell grain' \\
\hline & & ${ }^{\mathrm{HL}} \mathrm{k}^{\mathrm{h}} \mathrm{U}$ & 'string, thread' & $\mathrm{k}^{\mathrm{h}} \mathrm{ul} \mathbf{t} \mathbf{t c}^{\mathrm{h}} \mathbf{i} /$ & 'sell thread' \\
\hline $\mathrm{zrV}$ & 'raise & $\mathrm{H}_{\mathrm{ji}}$ & 'cow, ox' & ji $1 \mathrm{zgV}$ & 'raise cows' \\
\hline & (livestock)' & $\mathrm{HL}_{\mathrm{jo}}$ & 'sheep' & jol zrd & 'raise sheep' \\
\hline & & ${ }^{{ }^{L} H_{t s}}{ }^{h} \mathrm{u}$ & 'goat' & ts $\left.^{\mathrm{h}} \mathrm{u}\right\rfloor \mathbf{z r}_{\mathbf{r}} V$ & 'raise goats' \\
\hline gôl & 'make' & ${ }^{\mathrm{H}} \mathrm{ha}$ & 'food, grain' & halgov & 'cook food' \\
\hline & & $\mathrm{HL}_{\mathrm{tS}^{\mathrm{h}}{ }_{\mathrm{Wr}}}$ & 'evening meal' & $\mathrm{ts}^{\mathrm{h}} \mathrm{w \gamma} 7 \mathrm{gol}$ & 'cook dinner' \\
\hline & & $\mathrm{L}_{\mathrm{ZO}}$ & 'midday meal' & zo」go/ & 'cook lunch' \\
\hline laA & 'hit' & ${ }^{\mathrm{H}}$ ba.la & 'upper garment' & balla1 laV & 'knit garment' \\
\hline & & ${ }^{\mathrm{LH}}$ hwr & $\begin{array}{l}\text { 'decorative } \\
\text { pattern' }\end{array}$ & hwr」laV & 'embroider' \\
\hline & & $\mathrm{L}_{\mathrm{t} 6^{\mathrm{h}} \mathrm{O}}$ & 'ball' & t $6^{\mathrm{h}} \mathrm{O} J \mathrm{la} /$ & 'play ball' \\
\hline $\mathrm{p}^{\mathrm{h}} \mathrm{v} /$ & 'pour' & $\mathrm{H}_{\mathrm{ZuU}}$ & 'alcohol' & zul $1 \mathbf{p}^{\mathrm{h}}{ }_{1} V$ & 'pour alcohol' \\
\hline & & ${ }^{\mathrm{HL}} \mathrm{d} z \mathrm{i}$ & 'water' & dzi1 $\mathbf{p}^{\mathrm{h}} \mathbf{v} /$ & 'pour water' \\
\hline tsel & 'stitch' & $\mathrm{H}$ ba.la & 'upper garment' & balla tseV & 'sew garment' \\
\hline & & 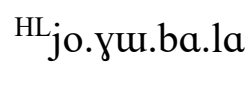 & $\begin{array}{l}\text { 'sheepskin } \\
\text { garment' }\end{array}$ & $\begin{array}{l}\text { jo †yuJbaJla」 } \\
\text { tṣe/ }\end{array}$ & $\begin{array}{l}\text { 'sew sheepskin } \\
\text { garment' }\end{array}$ \\
\hline
\end{tabular}

Table 18. Examples showing tonal realisations on verbs in $\mathrm{O}+\mathrm{V}$ tone groups.

As the examples in Table 18 suggest, $\mathrm{O}+\mathrm{V}$ tone groups are often determined by the tone of the noun. However, in the same way that exceptions occur to compound rules, there are also some unexpected tonal outputs in $\mathrm{O}+\mathrm{V}$ constructions. Sentence (18) above contains examples of this. The tone of [ $\mathrm{tg}^{\mathrm{h}}{ }_{\mathrm{v}}^{\mathrm{V}}$ ] 'breakfast' is high-falling in isolation and, in combination with the copula, appears as a $/ \mathrm{H} /$ category noun. However, when paired with the verb [gol/] 'to cook', the tonal category of $\mathrm{O}+\mathrm{V}$ becomes $/ \mathrm{LH} /$; the noun surfaces with a low tone and the verb with a high tone. A similar variant occurs for 'pour alcohol'. The noun 'alcohol' [zull] presents as a /H/ category noun in the $\mathrm{N}+\mathrm{COP}$ frame, and when in 
combination with the verbs [ $\left.\mathrm{t}^{\mathrm{h}} \mathrm{wV}\right]$ and $\left[\mathrm{p}^{\mathrm{h}} \mathrm{v} /\right]$, the $\mathrm{O}+\mathrm{V}$ tone groups surface as $/ \mathrm{H} /$. However, /LH/ is also given as an acceptable alternative for 'pour alcohol': /zuJ $\mathrm{p}_{\mathrm{h}}^{\mathrm{h}} \mathrm{V} /$. This alternative form, along with the existence of the /LH/ category compound noun /zuJ Jq ${ }^{\mathrm{h}} \mathrm{wr} /$ / 'alcohol bowl', shown in Table 17, is worthy of future investigation, as it may give clues as to earlier forms and historical developments pertaining to LTD Narua.

Tone groups comprised of $\mathrm{O}+\mathrm{V}$ are not restricted to simple nouns and verbs. Examples of tone groups comprised of longer noun phrases and a verb were seen in sentences (6)-(12) in Section 7.

Further, in clauses where no verb prefix is present but a post-verbal element such as the progressive marker [dzo] or a modal verb such as [kv/] 'can' appears, the surface tone of the entire verb phrase is determined by the preceding object noun. In the following two phrases, the tonal realisation of the progressive particle is determined by the tonal category of the noun $/{ }^{\mathrm{H}} \mathrm{ba} .1 \mathrm{la} /$ or $/ \mathrm{HL} b \mathrm{~b} /$, i.e. $[\mathrm{H}]$ and $[\mathrm{L}]$ respectively.

[balla1 mỵ1-dzol] 'upper.garment wear-PROG (wearing clothes)'

[bỵ $1 \mathrm{dzæ}$-dzod] 'yak ride- PROG (riding a yak)'

There are also cases where the noun is not the object of a transitive verb, but the verb is still included in the noun-headed tone group. In the following sentence from the text Almost Late for School (see appendix), the verb in the second clause, pronounced [gill] in isolation, is part of the tone group headed by the /HL/ category noun $/ \mathrm{HL}_{6 \mathrm{i}} / \mathrm{h}$ 'rain'. In this context, its surface tone is the same as in isolation.

(22) mụlzẹ

$/ \mathrm{H} /$

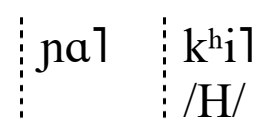

so 1 $/ \mathrm{H} /$

hot season when go.1.PST because rain fall

'(We) went in summer, so it was raining.'

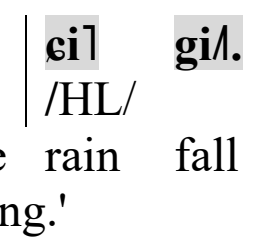

However, when the same verb collocates with $/{ }^{\mathrm{H}} \mathrm{bi} / \mathrm{snow}$ ', its surface tone changes according to the tonal category of the noun, viz. [bi1 giv] 'snow falls'. In these cases the noun, while it may be considered the grammatical subject of the clause, is neither agent nor patient.

\subsection{Number-classifier + verb constructions}

Similarly, where the tone group preceding a verb is comprised of a numberclassifier construction, the surface tone of the verb is determined by the tonal category of NUM-CLF. Compare the surface tone of the existential verb in the following two sentences which have previously been presented. In these sentences, NUM-CLASS $+\mathrm{V}$ form tone groups. 
(23) hĩ

\begin{tabular}{|c|c|c|c|c|}
\hline $\begin{array}{l}\text { hĩ1 } \\
\text { /H/ }\end{array}$ & $\begin{array}{l}\text { sol-kv」 } \\
\text { /HL/ }\end{array}$ & dzo/ & $\begin{array}{l}\text { pr7-bụ1 } \\
\text { /H/ }\end{array}$ & $\begin{array}{l}\mathrm{ts}^{\mathrm{h}}{ }^{\mathrm{v}} \backslash \mathrm{miV} \\
\text { /H/ }\end{array}$ \\
\hline rso & three-CLF & EXIST & $1 \mathrm{SG}-\mathrm{POSS}$ & wife \\
\hline & du1-luV & grV & sol-kט̣/ & \\
\hline & & /H/ & /HL/ & \\
\hline & one-CLF & $1 \mathrm{SG}$ & three- CLF & \\
\hline
\end{tabular}

'There are three people: my wife, a son, me, three (of us).'

(24) grาวฯ

/H/

$$
\text { zuldọ」 qoJlod zolmọ1 }
$$

1FAM /HL/

/H/

/L/

niltsil-kụl dzoV

/H/

child small-ATTR

twenty-CLF EXIST

'In our family there are twenty young children.'

The following excerpts from the appended text Almost Late for School demonstrate the surface tone of the verb [seV] 'walk' being determined by the preceding NUM-CL.

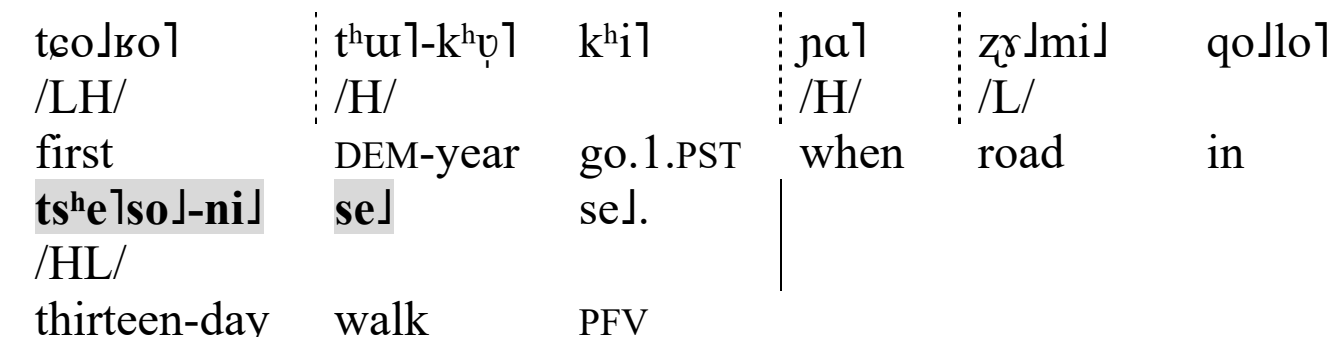

' The first year (I) went, (I) walked for thirteen days.'

(26)

$\begin{array}{ll:ll:llll}\text { zrdmi」 } & \text { qoJlo1 } & \text { hõ J-ni1 } & \text { se1 } & \text { tal } & \text { se1 } & \text { ji1 } & \text { tcalmọl. } \\ \text { /L/ } & & / \mathrm{LH} / & & & / \mathrm{H} ? / & & \\ \mathrm{road} & \text { in } & \text { eight-day } & \text { walk } & \text { only } & \text { walk } & \text { FUT } & \text { reckon }\end{array}$

'(I) reckoned (we'd) be walking on the road for only about eight days.'

\subsection{Tonal categories of verbs}

It has been observed that "verbs often present more complexity than nouns ... with respect to tone" (Hyman 2014:534). LTD Narua verbs are more complex than nouns and adjectives in that they may take prefixes, and with regard to their clause-final position in which their tonal realisations are prone to the influence of the preceding phonological environment. Despite this, it has proved possible to observe the tonal categories of verbs when they occur in the accomplished frame [lo-V se] 'ACCOM-V PFV'. The same is true for PJ Narua (Michaud 2008.) Even though it bears no structural resemblance to the $\mathrm{N}+\mathrm{COP}$ frame for nouns, or the ADJ-ATTR frame for adjectives, particularly given the presence of the prefix of accomplishment /lə-/, this frame was chosen for analysing tone categories of LTD 
Narua verbs because it brings out the maximum number of contrasts. Though not initially obvious, analysis on two tonal levels is also possible for verbs.

As previously stated, verbs - almost always monosyllables - appear as highfalling or low-rising in isolation. In other words, like monosyllabic nouns and adjectives, they appear with one of only two possible realisations. However, unlike nouns and adjectives, their isolation form does not predict their possible tonal output. In the perfective frame, there are three possible tonal realisations, regardless of whether the verb appears as high-falling or as low-rising in isolation. These are:

[L.H.H] with a clause final fall on the last syllable;

[H.H.H] with a clause final fall on the last syllable;

[H.L.L] with no contour on the last syllable.

Given that there are two possible isolation tones for verbs, and three possible tonal patterns in the perfective frame, a total of six tonal categories for verbs emerge $(2 \times 3=6)$.

\begin{tabular}{ccc}
\hline $\begin{array}{c}\text { Tone category } \\
\text { number }\end{array}$ & $\begin{array}{c}\text { Isolation tone } \\
\text { of verb }\end{array}$ & $\begin{array}{c}\text { Surface tones in } \\
\text { perfective frame }\end{array}$ \\
\hline 1 & $V$ & \rfloor $1 \mathrm{~V}$ \\
2 & $\mathrm{~V}$ & $11 \mathrm{~V}$ \\
3 & $\mathrm{~V}$ & $1\lrcorner 」$ \\
4 & 1 & $11 \mathrm{~V}$ \\
5 & 1 & $11 \mathrm{~V}$ \\
6 & 1 & $1 」 J$ \\
\hline
\end{tabular}

Table 19. Tonal categories of verbs in perfective frame[lo-V se]

Verbs from each of the above categories are shown in the perfective frame in Table 20 below, taking the verbs from Table 18 as examples where tokens are available.

\begin{tabular}{|c|c|c|c|c|}
\hline \multirow{2}{*}{$\begin{array}{c}\text { Tone category } \\
\text { number }\end{array}$} & \multicolumn{2}{|c|}{ Verb in isolation } & \multicolumn{2}{|c|}{ Verb in perfective frame } \\
\hline & dzuV & 'eat' & ləل-dzu1 seV & 'eaten' \\
\hline & nọV & 'bury' & lə」-nט̣1 seV & 'buried' \\
\hline \multirow[t]{2}{*}{2} & dziV & 'sit' & ləl-dzil seV & 'sat' \\
\hline & $t^{\mathrm{h}} \mathrm{wV}$ & 'drink' & lə1-th $\mathrm{tu} 1 \mathrm{seV}$ & 'drunk' \\
\hline \multirow[t]{2}{*}{3} & $\mathrm{t}^{\mathrm{h}}{ }^{\mathrm{i}} \mathrm{V}$ & 'sell' & lə1-t6hi」 se」 & 'sold' \\
\hline & $\mathrm{zrVV}$ & 'raise (livestock)' & ləl-z̧ $\rfloor$ se」 & 'raised' \\
\hline \multirow[t]{2}{*}{4} & gọ/ & 'make' & ləJ-gụl seV & 'made' \\
\hline & tsel & 'stitch' & ləJ-tsel seV & 'stitched' \\
\hline 5 & $\mathrm{q}^{\mathrm{h}} \mathrm{w} /$ & 'smash' & 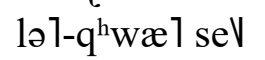 & ' smashed' \\
\hline \multirow[t]{2}{*}{6} & la/ & 'hit' & lə1-la」se」 & 'hit' \\
\hline & hæ̃/ & 'slice' & lə7-hæ̃」se」 & 'sliced' \\
\hline
\end{tabular}

Table 20. Examples of verbs in perfective frame[la-V se] 
Assigning labels to the six verb tonal categories is more problematic than for nouns or adjectives. In this regard, examining tone patterns of stative verbs is perhaps helpful. Where its tonal category when functioning as an attributive is known, this may be compared with tone realisation of the stative verb in the perfective frame. Observations of available data are summarised in the table below.

\begin{tabular}{|c|c|c|c|c|c|}
\hline $\begin{array}{l}\text { Tone } \\
\text { category as } \\
\text { adjective }\end{array}$ & \multicolumn{2}{|c|}{$\begin{array}{l}\text { Adjective } \\
\text { example }\end{array}$} & $\begin{array}{l}\text { Tone category } \\
\text { number in } \\
\text { perfective frame }\end{array}$ & \multicolumn{2}{|c|}{$\begin{array}{l}\text { Stative verb in } \\
\text { [lo-V se] frame }\end{array}$} \\
\hline$/ \mathrm{H} /$ & $\mathrm{H}_{\mathrm{t} 6^{\mathrm{h}} \mathrm{i}}$ & 'happy' & 1 & ləJ-t ${ }^{\mathrm{h} i} 1-\mathrm{seV}$ & 'become happy' \\
\hline /HL/ & $\mathrm{HL} \mathrm{th}^{\mathrm{h}}$ & 'tired' & 2 & le1-thi1-seV & 'become tired \\
\hline /L/ & ${ }^{\mathrm{L}} \mathrm{mv}$ & 'ripe & 4 & ləJ-mụl-seV & 'become ripe' \\
\hline /LH/ & ${ }^{{ }^{\mathrm{L}} \mathrm{t}^{\mathrm{h}} \mathrm{a}}$ & 'sharp' & 6 & le1- $t^{\mathrm{h}} \mathrm{a} J-\mathrm{se}$ & 'become sharp' \\
\hline
\end{tabular}

Table 21. Examples of adjectives cf. stative verbs in perfective frame

Based on these observations, tone categories 1, 2, 4, and 6 could be analysed as $/ \mathrm{H} /, / \mathrm{HL} /, / \mathrm{L} /$, and $/ \mathrm{LH} /$ respectively. There are a number of problems with this, however. Firstly, although the above table is an accurate reflection of the available data, a fuller investigation would need to be carried out in order to be confident of correspondences between tonal categories of a lexical item as an adjective and the same item as a stative verb. Secondly, there exists at least one exception to the above findings: $/{ }^{\mathrm{H}} \mathrm{fo} / \mathrm{\prime}$ 'dry' emerges with a category 3 tone pattern in the perfective frame, not category 1 . Thirdly, the problem remains of what to label categories 3 and 5, especially given that the other four labels bear little resemblance to their actual tonal realisations. In addition, it is not fully understood why the final tone of [H.L.L] in category 3 and 6 groups does not surface with a clause-final rise.

\section{CONCLUSION}

Analysis of the tonal system of LTD Narua is not yet complete. Further work needs to be done regarding tonal categories of verbs, apparent irregularities in the tone system need to be further investigated, and the placement of tone group boundaries also requires further study. In addition, the integration of Chinese loan words into the phonological system of LTD Narua would make fascinating research. Changes will no doubt be made to this description as data collection and analysis progress.

The authors are confident, however, that the basic thesis of this paper is accurate: that, unlike other Naish languages described to date, LTD Narua makes use of only two tonal levels. This is a significant finding in the ongoing study of these languages. This description also adds to the growing collection of data regarding Sino-Tibetan languages in which level tones are primary, and tones are associated to lexical items rather than to individual syllables. 


\section{ABBREVIATIONS}

(?) Tonal category as yet unknown

ABL Ablative

ADJ Adjective

ACCOM Accomplished marker

ATTR Attributive marker

CLF Classifier

COP Copula

DEM Demonstrative pronoun

DUR Durative marker

EXIST Existential verb

FAM Family suffix

FUT Future

N Noun

NEG Negative

NMLZ Nominaliser

NP Noun phrase

NUM Number

O Object

PFV Perfective marker

PL Plural

POSS Possessive

PROG Progressive marker

PST Past

Q Question

SG Singular

SOV Subject-Object-Verb

TOP Topic marker

V Verb

VP Verb phrase

\section{APPENDIX: LATADDI NARUA TEXTS}

Notes: Tone, transcribed using Chao letters, is shown at surface phonological level, i.e. as realised in context.

Chinese loanwords interspersed throughout the text are transcribed in italics using Hanyu pinyin, i.e. remaining non-committal about their integration into the Narua phonological system, including that of tone.

\section{CHILDREN}

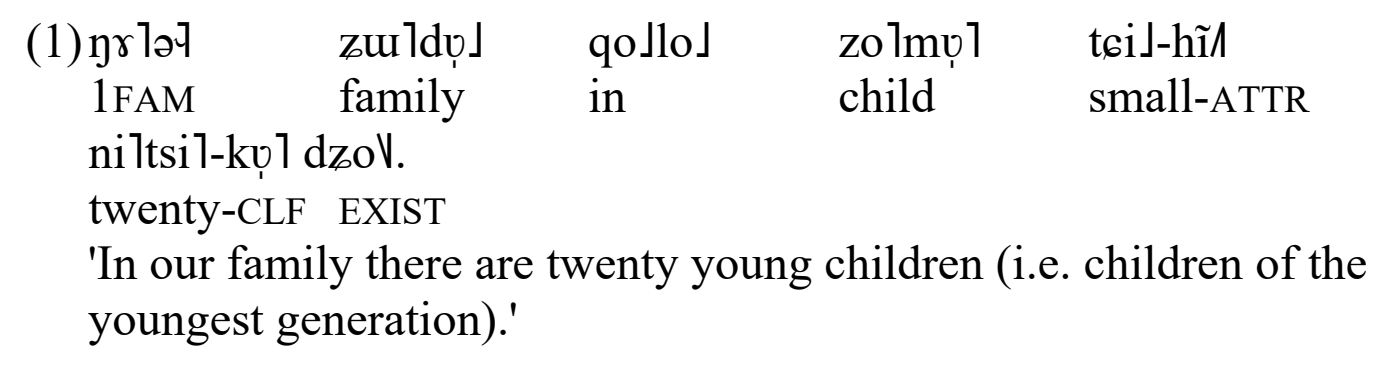



(2) zu/ a аাво」 zo ไmọ1
tci」-hĩl dulvọl
th $^{\mathrm{h}} \mathrm{i}$ 1-mə7- dzoV.
now home child
small-ATTR one-CLF
DUR-NEG-EXIST
'Now there is not one small child at home.'

\section{DAILY LIFE}

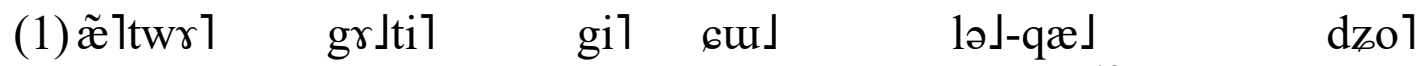 dawn get up after incense ACCOM $^{19}$-burn CONJ li」 $\mathrm{t}^{\mathrm{h}} \mathrm{w}$. tea drink

'At dawn, after getting up, having burnt incense, (we) drink tea.'

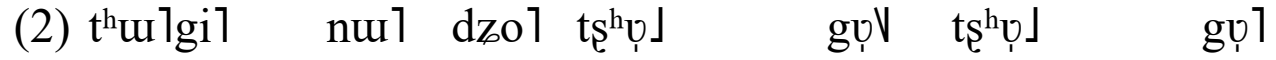 next ABL TOP breakfast cook breakfast cook sol dzul.
in order to eat
'Next (we) cook breakfast, cook breakfast to eat.'
(3) ts $\mathrm{s}^{\mathrm{h}} \mathrm{1}$ lə1-dzul loJti1 biv.
breakfast ACCOM-eat manual labour go
'Having eaten breakfast, (we) go to work.'
(4) loJti1 qo1lo1 nul tiddza」 duJ-kh ${ }^{\mathrm{h}} \mathrm{w} 1 \mathrm{dzul}$. manual labour in ABL snack one-CLF.bit eat 'During work, (we) eat a snack.'

(5) ti」dza」 lə」dzul gil lo1 dul-ts ${ }^{\text {h }} 1$ iv. snack ACCOM-eat after work one-CLF.time do 'After eating a snack, (we) do work for a while.'

(6) ts' 1 nul dzol zo」 gọ sol zo」 dzw/. there $\mathrm{ABL}$ TOP lunch cook in order to lunch eat 'Next (we) cook lunch to eat lunch.'

(7) zo」 dzw」 gi1 lo1 luil îl. lunch eat after work return do 'After eating lunch, (we) go back to doing work.'

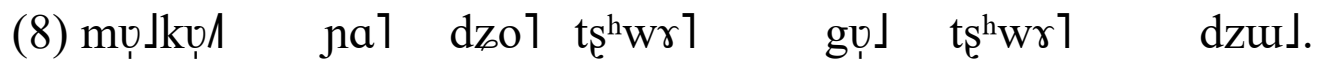 evening when TOP dinner cook dinner eat 'When it's evening, (we) cook dinner (and) eat dinner.'

\section{ALMOST LATE FOR SCHOOL}
(1) yrl xiaoxue
so」
na1
$t^{\text {h }}$ æ\วᄀ-so 1-во 1
$1 \mathrm{SG}$ primary school
study
so」
when
se」.
three-CLF in
study
book-study-place
'When I was at primary school, (I) studied in three schools.'

${ }^{19}$ ACCOM: Accomplished marker 


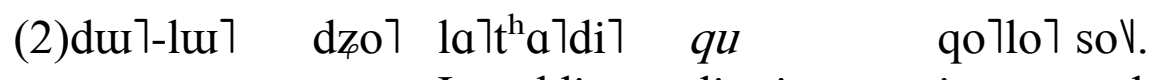
one-CLF TOP Lataddi district in study

'One (place) was in Lataddi district.'

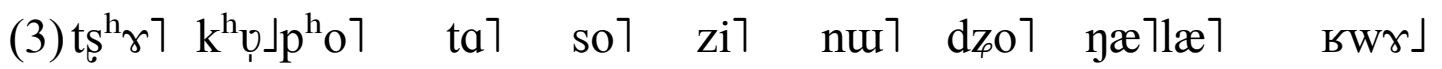
there half year only study still ABL TOP 1PL village

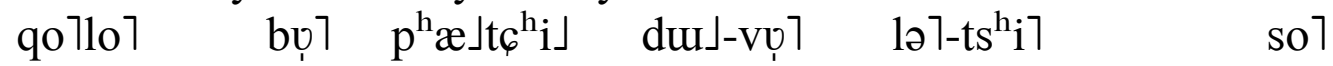
in POSS man one-CLF ACCOM-come in order to

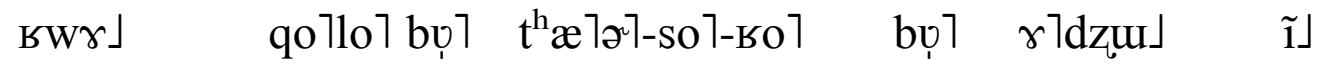
village in POSS book-study-place POSS teacher do lo」-ts ${ }^{\mathrm{h}} \mathrm{i}$.

ACCOM-come

'After studying there for only half a year, a man from our village came back to be a teacher in the village school.'

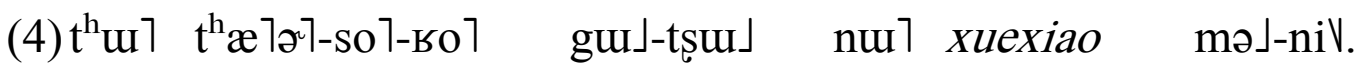
DEM book-study-place true-tell ABL school NEG-COP. 'This school actually wasn't a school.'

\begin{tabular}{|c|c|c|c|}
\hline (5) פชาlu1 & $\left.\left.\operatorname{tss}^{\mathrm{h}}{ }^{v} 7 \mathrm{mi}\right\rceil-1 \mathrm{u}\right\rceil$ & bụ 7 & $\mathrm{t}^{\mathrm{h}} \mathrm{u}$-tşæ $\rceil$ \\
\hline 1FAM & wife-FAM & POSS & DEM-time \\
\hline mə」-tseา-hñ̄ & 1la」-zu」 ni」. & & \\
\hline NEG-use-ATTR & god-room & & \\
\hline
\end{tabular}

'(It) was one of our uncles' wife's family's god-room that wasn't being used at the time.'

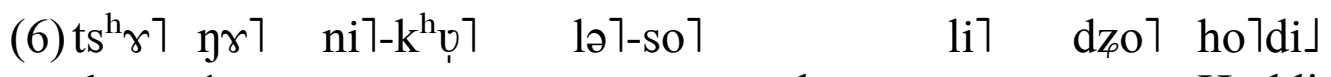
there 1SG two-year ACCOM-study CONJ TOP Hoddi so」 $\left.\mathrm{k}^{\mathrm{h}} \mathrm{i}\right\rfloor$ se」. study go.1.PST PFV

'After studying there for two years I went to study at Hoddi.'

(7) ho $7 \mathrm{di」}$ dzo 7 Yanyuanxian bụ 7 xiancheng niv. Hoddi TOP Yanyuan county POSS county seat COP 'Hoddi is the county seat of Yanyuan county.'

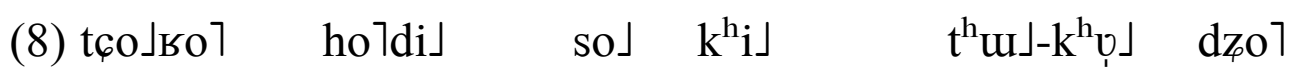
first Hoddi study go.1.PST DEM-year TOP yฬ7 xiaoxue sannianji so」-hĩ」 niv. 1SG primary school third year study-ATTR CERT 'The first year (I) went to study at Hoddi, I was in primary school year three.'

(9) holdi」

$\left.\left.\mathrm{k}^{\mathrm{h}} \mathrm{i}\right\rfloor-\mathrm{h} \tilde{\mathrm{I}}\right\rfloor$

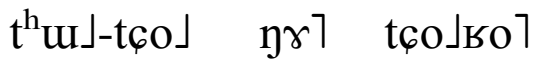
Hoddi go.1.PST-ATTR $\left.\mathrm{k}^{\mathrm{h}} \mathrm{i}\right\rceil$-hĩ dult 607 DEM-time 1SG first niV. go.1.PST-NMLZ one-time CERT 'This time going to Hoddi was the first time I'd been so far away.' 


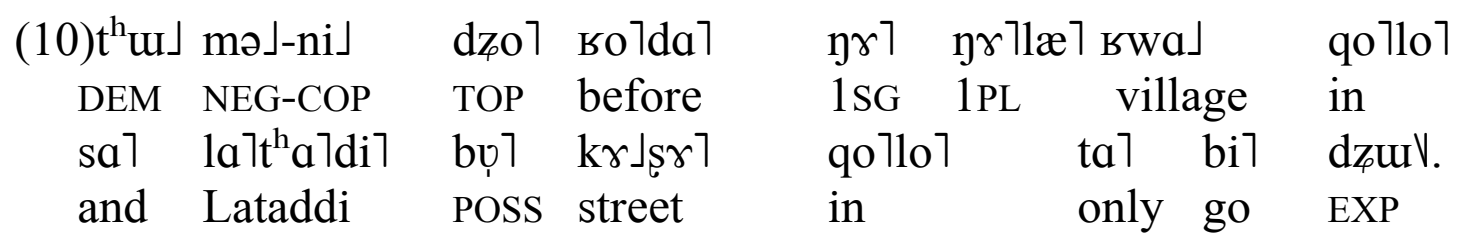

'Otherwise, I had only been to our village and Lataddi town before.'

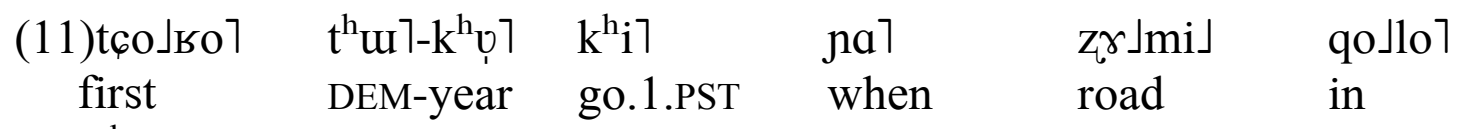

ts $\left.{ }^{\mathrm{h}} \mathrm{e} \backslash \mathrm{so}\right\lrcorner$-ni」 se」 se」.

thirteen-day walk PFV

'The first year (I) went, (we) walked for thirteen days.'

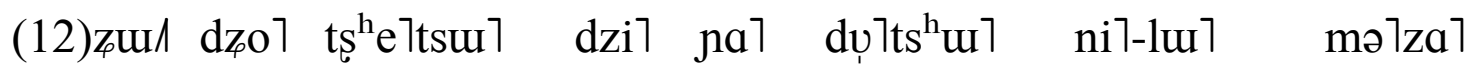
now TOP car sit when hour two-CLF NEG.limit

nee 7 ho $\left.\backslash d i 」 \quad \mathrm{t}^{\mathrm{h}} \mathrm{v}\right\rfloor$.

ABL Hoddi arrive

'Nowadays, going by car, it takes two and a bit hours to get to Hoddi.'

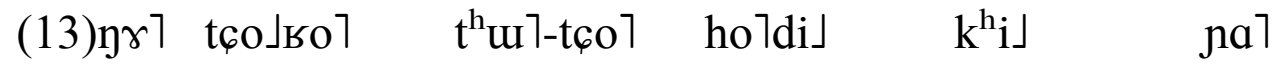
$1 \mathrm{SG}$ first DEM-time Hoddi go.1.PST when

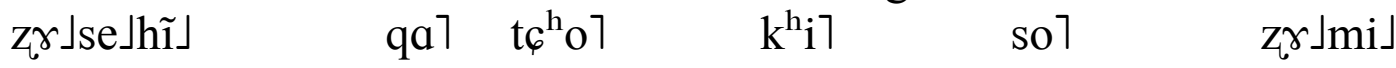
horse-walk-person COM accompany go.1.PST because road qo $\lrcorner l o 7 \quad$ ts $\left.^{\mathrm{h}} \mathrm{e}\right\rceil$ so $\lrcorner-n i 」$ se $\rfloor$ se $\lrcorner$. in thirteen-day walk $\mathrm{PFV}$

'The first time I went to Hoddi, (I) went with horse couriers, so it took thirteen days to walk.'

(14)æไtsul-ĩ」-so」 o’niך duJ-tşæ」 se」 læ7. what-do-for this way one-time walk $Q$ 'So why (did it take thirteen days) to walk this time?'

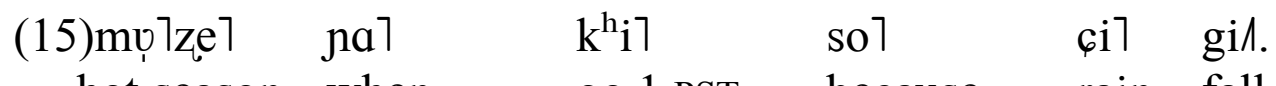
hot season when go.1.PST because rain fall '(We) went in summer, so it was raining.'

(16) wr/ dzo 1 also TOP so7

because mə7-вטิV.

NEG-can

'Also, (we) went with horse couriers, so (we) couldn't walk very far in a day.'

(17)duJ-k $\mathrm{k}^{\mathrm{h}} \mathrm{w} \gamma 7 \mathrm{du} 7-\mathrm{k}^{\mathrm{h}} \mathrm{w} \gamma 7$ qo $71 \mathrm{lo}$ one-place one-place in zy t $\left.^{\mathrm{h}} \mathrm{i}\right\rceil$ hu 7 horse run off tso 7 $t^{\mathrm{h}} \mathrm{v} V$.

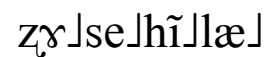

qa $7 t_{6}^{\mathrm{h}} \mathrm{o} 7$ $\left.\mathrm{k}^{\mathrm{h}} \mathrm{i}\right\rceil$ horse-walk-person-PL COM accompany go.1.PST

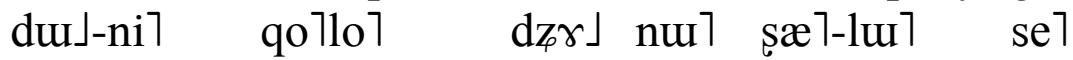
one-day in much ABL far-CLF walk 
have to go out

'At one place where (we) stayed overnight the horses ran off, so (we) had to go out and look for them.'

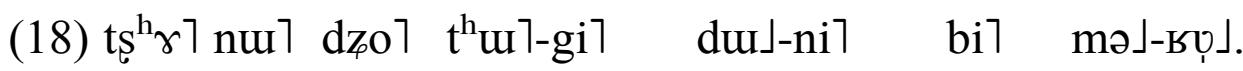
then ABL TOP DEM-after one-day go NEG-can 'Then the next day (we) couldn't go (on).'

(19)sulp $\mathrm{p}^{\mathrm{h}}$ 1 $\quad$ во 7 to 7

Sipo mountain top zy 1 se 7

so 1 dzol so7-ni」 $\left.\quad \mathrm{t}^{\mathrm{h}} \mathrm{u}\right\lrcorner$ dze $\rfloor$. three-day DUR-delay '(We) looked for the horses on Sipo mountain, so were delayed for three days.'

(20) zỵ la7-șe 7

horse ACCOM-look for $\mathrm{k}^{\mathrm{h}} \mathrm{i} / \quad$ dulta 7 lə7-do7 gi7 vọ go.1.PST altogether ACCOM-see after animal ACCOM-load $\mathrm{t}^{\mathrm{h}} \mathrm{J}$. arrive

'After finding the horses (we) loaded the animals up, altogether (we) walked for thirteen days before arriving at Hoddi.'

(21)ts $\left.\left.{ }^{\mathrm{h}} \mathrm{e} \backslash \mathrm{so}\right\rfloor-\mathrm{ni}\right\rfloor$ thirteen-day z̧wæ/ ni」 seV. very CRS PFV se」 sol walk because $1 \mathrm{SG}$ heart qo $\ 107$

in

'Because (we) walked for thirteen days, I was feeling very anxious.'

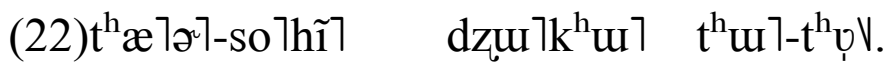

book-study-ATTR time DUR-arrive

'The time for school to start had already arrived.'

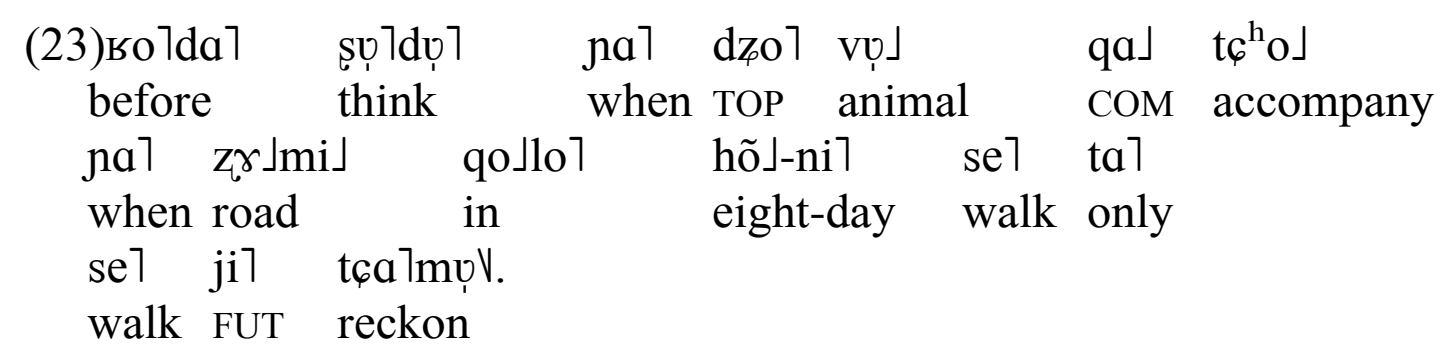

'Previously, when (I'd) thought about travelling with the animals, (I ) reckoned (we'd) be walking on the road for only about eight days.'

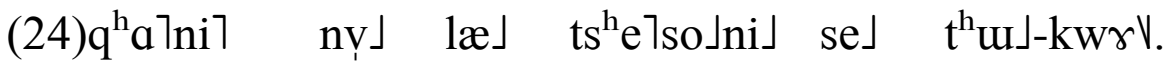
how know Q thirteen-day walk DUR-take (time)

'How (was I to) know (we) would walk for thirteen days?'

\begin{tabular}{|c|c|c|}
\hline (25)holdi」 & 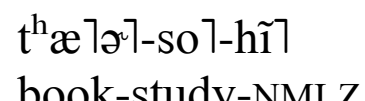 & qo 7107 \\
\hline
\end{tabular}


gr7 dul-tsul ta7 di $7 \mathrm{t}^{\mathrm{h}} \mathrm{w}$ 1-mo7-æ7tse 7 mæV. EMPH.time one-bit only NMLZ DEM-NEG-attain EMPH ' (I) almost didn't make it in time to enrol for school in Hoddi.'

\section{REFERENCES}

Chirkova, Katia. 2009. Shǐxīng, a Sino-Tibetan language of south-west China: a grammatical sketch with two appended texts. Linguistics of the Tibeto-Burman Area 32(1).1-89.

Chirkova, Katia \& Alexis Michaud. 2009. Approaching the prosodic system of Shǐxīng. Language and Linguistics 10(3). 539-568.

Daudey, Henriëtte. 2014. A grammar of Wadu Pumi. Ph.D. dissertation, La Trobe University. Available online at: https://www.academia.edu/8879093/A_Grammar_of_Wadu_Pumi

Ding, Picus Sizhi. 2001. The pitch accent system of Niuwozi Prinmi. Linguistics of the Tibeto-Burman Area 24(2).57-83.

Ding, Picus Sizhi. 2014. A Grammar of Prinmi: based on the central dialect of Northwest Yunnan, China. Leiden: Brill.

Evans, Jonathan. 2008. "African" tone in the Sinosphere. Language and Linguistics 9(3). 463-490.

Hé Jírén (和即仁) \& Jiāng Zhúyí (姜竹仪). 1985. 纳西语简志 [A Brief Outline of the Naxi Language]. Beijing: Nationalities Publishing House.

Hyman, Larry M. 2007. Elicitation as experimental phonology: Thlangtlang Lai tonology. In Patrice Speeter Beddor, Maria Josep Solé \& Manjari Ohala (eds.), Experimental Approaches to Phonology, 7-24. Oxford: Oxford University Press.

Hyman, Larry M. 2014. How to study a tone language, with exemplification from $\mathrm{Oku}$ (Grassfields Bantu, Cameroon). Language Documentation \& Conservation 8.525-562.

Hyman, Larry M. \& Kenneth VanBik. 2002. Tone and stem2 formation in Hakha Lai. Linguistics of the Tibeto-Burman Area 25. 113-121.

Jacques, Guillaume. 2011. A panchronic study of aspirated fricatives, with new evidence from Pumi. Lingua 121(9).1518-1538.

Jacques, Guillaume \& Alexis Michaud. 2011. Approaching the historical phonology of three highly eroded Sino-Tibetan languages: Naxi, Na and Laze. Diachronica 28.468-498.

Lidz, Liberty A. 2010. A descriptive grammar of Yongning Na (Mosuo). Ph.D. dissertation, University of Texas at Austin. Available online at: http://repositories.lib.utexas.edu/handle/2152/ETD-UT-2010-12-2643

Michailovsky, Boyd, Martine Mazaudon, Alexis Michaud, Séverine Guillaume, Alexandre François \& Evangelia Adamou. 2014. Documenting and researching endangered languages: The Pangloss Collection. Language documentation \& conservation 8.119-135. 
Michaud, Alexis. 2006. Tonal reassociation and rising tonal contours in Naxi. Linguistics of the Tibeto-Burman Area 29(1).61-94.

Michaud, Alexis. 2008. Phonemic and tonal analysis of Yongning Na. Cahiers de Linguistique Asie Orientale 37(2).159-196.

Michaud, Alexis. 2009. The prosodic system of Muli Shuitian (Laze). Minority Languages of China 6.28-33. Available online at: http://halshs.archivesouvertes.fr/halshs-00436463

Michaud, Alexis. 2013. Studying level-tone systems in Asia: the case of the Naish languages. Proceedings of International Conference on Phonetics of the Languages in China (ICPLC-2013), 1-6. Hong Kong.

Michaud, Alexis. 2015. Phrasing, prominence, and morphotonology: How utterances are divided into tone groups in Yongning Na. Bulletin of Chinese Linguistics (8). 112-152.

Michaud, Alexis \& He Likun. 2015. Phonemic and tonal analysis of the Pianding dialect of Naxi (Dadong County, Lijiang Municipality). Cahiers de linguistique - Asie Orientale 244(1).1-35 plus online Appendices. doi:10.1163/19606028-00441p01.

Michaud, Alexis \& He Xueguang. 2007. Reassociated tones and coalescent syllables in Naxi (Tibeto-Burman). Journal of the International Phonetic Association 37(3).237-255.

Pinson, Thomas M. 1997. Naxi phonology: A flat phonemic statement of the Longquan dialect. Unpublished.

Sun, Jackson T.-S. 1997. The Typology of Tone in Tibetan. Chinese Languages and Linguistics IV: Typological studies of languages in China, 485-521. Taipei, Taiwan: Symposium Series of the Institute of History and PhilologyAcademia Sinica.

Yáng Zhènhóng (杨振洪). 2006. An overview of the Mosuo language. 拉 Lātāmī Dáshí (他咪达石) (ed.). A collection of essays on Mosuo society and culture 1960-2005, vol. 2.28-64. Kunming: Yunnan University Publishing House.

Yáng Zhènhóng (杨振洪), transl. Liberty Lidz. 2009. An overview of the Mosuo Language. Linguistics of the Tibeto-Burman Area 32(2). 1-44. 